DEPARTMENT OF 'THF INTERIOR

UNITED STATES GEOLOGICAL SURVEY

GEORGE OTIS SMITH, DIRECTOR

BULLETIN 437

\title{
RESULTS OF SPIRIT LEVELING
}

IN

\section{MAINE, NEW HAMPSHIRE, AND VERMONT}

1896 T'0 1909, INCLUSIVE

R. B. MARSHALL, Chief Geographer

WORK DONE IN COOPERATION WITH THE STATE OF MAINE DURING 1899 TO 1909, INCLUSIVE

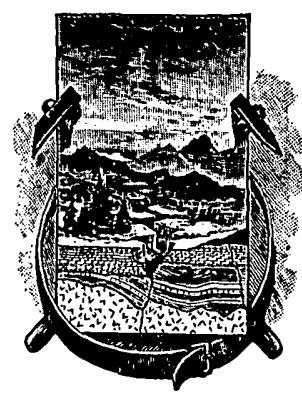

WASHINGTON

GOVIRNMN'T PRINTING OFICE

1910 



\section{CONTENTS.}

Page.

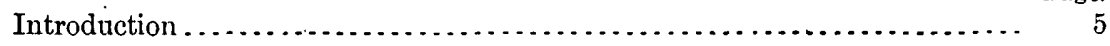

Scope of the work ........................................ 5

Personnel................................................... 5

Classification............................................... 6

Bench marks .................................................. 6

Maine .......................................................... 7

Precise leveling ............................................ 7

Bath, Freeport, Gray, Kezar Falls, Portland, and Sebago quadrangles (Cumberland and Oxford counties) ..................... 7

Prımary leveling ....................................... 9

Anson, Augusta, Bingham, Brassua Lake, Moosehead Lake, Norridgewock, Skowhegan, The Forks, Vassalboro, and Waterville quadrangles (Kennebec, Somerset, and Piscataquis counties).............

Buckfield, Lewiston, Livermore, Norway, and Poland quadrangles (Androscoggin, Cumberland, Franklin, Kennebec, Oxford, and Sagadahoc counties) ........................................

Bethel, Fryeburg, Kezar Falls, and Rumford quadrangles (Cumberland, Oxford, and York counties) .........................

Belfast, Castine, and Rockland quadrangles (Knox and Waldo coun-

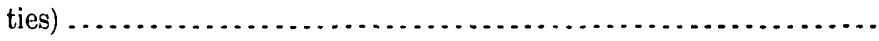

Bangor, Bluehill, Bucksport, Ellsworth, Mount Desert, Orland, and Orono quadrangles (Hancock, Penobscot, and Waldo counties)....

Lincoln, Mattawamkeag, Millinocket, Passadumkeag, and Winn quadrangles (Penobscot County) ..............................

Cherryfield quadrangle (Washington County) ....................

Cutler and Eastport quadrangles (Washington County).............

Augusta, Bath, Bethel, Buckfield, Dixfield, Freeport, Gardiner, Lewiston, Livermore, and Rumford quadrangles (Androscoggin, Curnberland, Franklin, Kennebec, Oxford, and Sagadahoc counties)...

Several unnamed quadrangles (Penobscot, Piscataquis, and Somerset

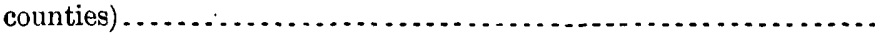

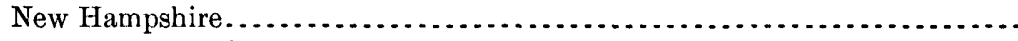

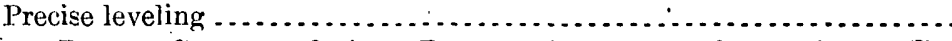

Benton, Campton, Ossipee, Rumney, Silver Lake, Squam Lake, Winnepesaukee, and Woodsville quadrangles (Belknap, Carroll, and Grafton counties)

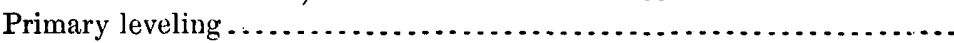

Boscawen, Squam Lake, and Winnepesaukee quadrangles (Belknap, Carroll, and Grafton counties) ..............................

Claremont, Concord, Dôver, Hanover, Haverhill, Manchester, Mascony Lake, Milford, Mount Kearsarge, Nottingham, Peterboro, Sunapee, Suncook, and York quadrangles (Cheshire, Grafton, Hillsboro, Merrimac, Rockingham, and Sullivan counties) ...................

Whitefield quadrangle (Coos and Grafton counties) ...............

Gorham and Milan quadrangles (Coos County) .................... 7

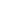
9 . 
Page.

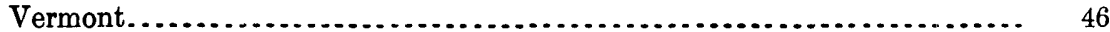

Precise leveling ............................................. 46

Hanover, Thetford, and Woodsville quadrangles(Orange and Windsor counties) ............................................. 46

Primary leveling ............................................ 47

Claremont and Hanover quadrangles (Windsor County) ......... 47

Whitefield quadrangle (Essex County) ......................... 49

Burlington, Brandon, Camels Hump, Middlebury, Milton, Potato Hill, and Ticonderoga quadrangles (Addison, Crittenden, and Rutland counties) ........................................ 49

Bennington quadrangle (Bennington County) $\ldots \ldots \ldots \ldots \ldots \ldots \ldots \ldots . .52$

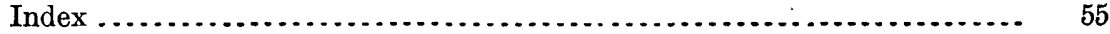




\section{RESULTS OF SPIRIT LEVELING IN MAINE, NEW HAMP- SHIRE, AND VERMONT, 1896 T0 1909, INCLUSIVE.}

R. B. Marshall, Chief Geographer.

\section{INTRODUCTION.}

Scope of the work.-The results herein given are based on a common mean sea-level datum. The main control is the adjustment made in 1903 by the Coast and Geodetic Survey of a great net of precise levels which combines work of various organizations and covers the eastern half of the United States. The precise-level lines which lie wholly or partly in these States are (1) from Portland northeast along the Maine Central Railroad to Brunswick, Me.; (2) from Portland along the Maine Central Railroad to Cornish, thence west along highways to the New Hampshire-Maine state line, thence westward via Lake Winnepesaukee across New Hampshire to South Newbury, Vt., thence down the Connecticut River Valley to White River Junction, Vt., where a check was obtained on a bench mark established by primary leveling extended from a tidal bench mark near Portsmouth, N. H.

All results of spirit leveling in these States previously published by the United States Geological Survey and all later work are included in this report, readjusted and rearranged by quadrangles. Descriptions and elevations of bench marks are given for 15 out of 16 counties in Maine, for 9 out of 10 counties in New Hampshire, and for 7 out of 14 counties in Vermont.

The results of leveling by the water resources branch in Maine and New Hampshire are also included.

Personnel.-The field work during 1898 to 1906 , inclusive, was done under the direction of H. M. Wilson, geographer, and that during 1907 to 1909 , inclusive, was done under Frank Sutton, geographer. The work since January, 1908, was done under the general direction of R. B. Marshall, chief geographer. Credit is given in the heading of each list to the different levelmen.

The leveling in Maine was done in cooperation with the State during the years 1899 to 1909 , inclusive. The leveling in New Hampshire and Vermont was not done in cooperation with the States. 
The office work of computation and compilation of results was done by $\mathrm{D}$. H. Baldwin, topographer, under the immediate supervision of S. S. Gannett, geographer, and since 1907 under the general direction of E. M. Douglas, geographer.

Classification.-The lists are separated into two classes; precise and primary, distinguishing the degree of refinement in the method of leveling employed; and each list is subdivided so that the results for each quadrangle are combined. The elevations under precise leveling were determined by lines run in both forward and backward directions, a high-grade level and rated rods being used and special precautions being taken in observation and reduction to correct error and make the results continuously good; elevations under primary leveling were determined mostly by single lines run with the $Y$ level, precautions being taken against only the principal sources of error, and depending upon the closure of circuits for a check. The allowable limit of error observed on the precise lines is represented in feet by the formula $0.017 \sqrt{\mathrm{D}}$, in which $\mathrm{D}$ is the distance between bench marks in miles. The limit in feet on primary work is $0.05 \sqrt{\bar{D}}$, in which $D$ is the length of circuit in miles.

Bench marks. - The bench marks, the locations of which are given in the following lists, are of three general forms: First, a circular bronze or aluminum tablet $3 \frac{1}{2}$ inches in diameter and one-fourth inch thick, appropriately lettered, having a 3 -inch stem cemented in a drill hole, generally in the vertical wall of a public building, a bridge abutment, or other substantial masonry structure. The second form, employed where masonry or rock is not accessible, consists of a hollow wroughtiron post $3 \frac{1}{2}$ inches in outer diameter and 4 feet in length; split at the bottom and expanded to 10 inches at base, so as to prevent both the easy subsidence of the post and the malicious pulling of it out of the ground. These posts are generally sunk 3 feet in the ground; the iron is heavily coated with asphalt, and over the top of the post is riveted a bronze tablet similar to that described above. The third form consists of a copper bolt 1 inch in diameter and 4 inches long, which is split at one end and expanded in a drill hole in masonry by driving on a brass wedge. But few bench marks of the third class have been used in these States, and their use has now been discontinued.

The numbers stamped on the bench marks represent the elevations to the nearest foot above mean sea level, as determined by unadjusted levels in the field. The notes have since been subjected to changes resulting from the adjustments necessary to close circuits and to reduce to mean sea level through connection with or readjustment of the precise-level net of the United States. Some of the elevations as finally accepted and printed herein therefore differ from those submitted as bench-mark numbers by 1 or 2 feet. This method of numbering bench marks, rather than any attempt at serial numbering, has 
been adopted where many levelmen are working in a given area at the same time as less liable to lead to confusion in identification of bench marks and because such bench-mark number also affords an approximate statement of the elevation. It is assumed that engineers and others finding these bench marks so stamped in the field will communicate with the Director of the United States Geological Survey in order to obtain the accepted elevation to hundredths or thousandths of a foot. Bench marks established under cooperation are stamped with the state name.

For a complete list of standard bench marks in any quadrangle refer to both precise and primary lists. Descriptions of bench marks in adjoining States, but within the border quadrangles herein listed, are not given in this bulletin.

Any person finding bench marks in the following lists mutilated or destroyed will confer a favor by notifying the Director, United States Geological Survey, Washington, D. C.

MAINE.

PRECISE IEVEIING.

Bath, Freeport, Gray, Kezar Falls, Portland, and Sebago quadrangles.

CUMBERLAND AND OXFORD COUNTIES.

The elevations in the following list are the result of two lines of precise levels run in 1906: One line from Portland, northeast along the Maine Central Railroad, to Brunswick (where it joins the doublerodded primary line of the water-resources branch from Augusta), and thence up the Androscoggin River; the other line from Portland, northwest along the Maine Central Railroad, to Cornish, and thence west along highways through the southern part of Kezar Falls quadrangle to the New Hamsphire state line. Both lines are based on a bench mark established by the United States Engineer Corps in 1901 from previous ones set by the Coast and Geodetic Survey, now destroyed, the heights of which were determined from tidal records made in 1852-53 and in 1864-1866. The bench mark is the bottom of a $\frac{1}{2}$-inch drill hole one-eighth inch deep on upper surface of water table between columns at right of the Commercial street entrance to the custom-house building. Its elevation is 14.069 feet above mean sea level and the mean range of tide at Portland as corrected in 1896 is 8.824 feet. The methods, instrument, and limit of error were practically those now used by the Coast and Geodetic Survey, except that the rods were 3.5 yards long, graduated to yards and hundredths with incased thermometers.

The lines are leveled independently in both forward and backward directions, broken by temporary bench marks into sections 0.5 mile to 1.25 miles long. On all sections upon which the backward and 
forward measures differed in feet more than 0.017 times the square root of the distance between bench marks in miles, the line was rerun until a pair in opposite directions came within limits. All corrections necessary to obtain accurate results were made.

The leveling was done by N. A. Campbell, chief of the party.

PORTLAND QUADRANGLE.

PORTLAND, NORTHEAST ALONG MAINE CENTRAL RAILROAD, TO CUMBERLAND JUNCTION.

Portland, on step at right side of main entrance to city hall; bronze tablet stamped "67".

Feet.

Portland, on upper surface of water table between columns at right of Commercial street. entrance to custom-house, bottom of $\frac{1}{2}$-inch drill hole one-eighth inch deep (above low water, 18.481)...............

Portland, 0.9 mile south of custom-house, on foundation of highway bridge over railroad, east side of track; chiseled square.................

Portland, right side of main entrance to Union Station; aluminum tablet stamped " 26 ".

Woodfords, in front of station; top of rail . . . . . . . . . . . . . . . . . . . .

Deering Junction, in front of station; top of rail. ..................

Deering Junction, 0.2 mile northeast of, southeast side of track, 225 feet northeast of highway, in west side of granite ledge; aluminum tablet stamped " $110 "$.

Deering Junction, 2.9 miles northeast of, railroad bridge over Presumpscot River, northwest side of track, on top of northeast abutment; aluminum

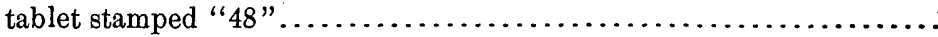

103.8

109. 530

PORTLAND, ALONG MAINE CENTRAL RAILROAD, TO NEWHALL.

Portland, on right side of main entrance to Union Station (porte-cochère), in curb; aluminum tablet stamped " 26 ".

Cumberland Mills, 0.2 mile northwest of, south side of track, west abutment of railroad bridge, in retaining wall; aluminum tablet stamped " 65 " (error in stamping).

South Windham, 110 feet east of first road east of station parallel with railroad, south of $T$ road, 3 feet higher than road, in rock ledge; aluminum tablet stamped " 154 ".

Newhall, in front of station; top of rail..............................

GRAY QUADRANGLE.

AT CUMBERLAND JUNCTION.

Cumberland Junction, 250 feet south of station, southeast side of track, top of culvert; aluminum tablet stamped " 58 ".

Cumberland Junction, in front of station; top of rail..................

FREEPORT QUADRANGLE.

CUMBERLAND JUNCTION, NORTHEAST ALONG MAINE CENTRAL RALLOAD, TO BRUNSWICK.

Cúmberland Junction, 3.6 miles northeast of, bridge over Royal River, northwest side of track, on top of south abutment; aluminum tablet stamped " 92 ".

91. 794

Yarmouth Junction, in front of station; top of rail.

89.8

Yarmouth, 1.7 miles northeast of, 364 feet southwest of overhead highway bridge, southeast side of track, on ledge; chiseled square 
Yarmouth Junction, 4 miles northeast of, southwest end of southeast abutment of overhead highway bridge; aluminum tablet stamped " 90 ".....

Freeport, in front of station; top of rail...........................

Freeport, 0.2 mile northeast of, northwest side of track just south of highway, in rock ledge; aluminum tablet stamped " 133 ".

Freeport, 4.1 miles northeast of, southeast side of track, in rock ledge; aluminum tablet stamped " 136 ".

\section{BATH QUADRANGLE.}

AT BRUNSWICK.

Brunswick, west side of Union Station, about 16 feet from southwest corner of grating over basement windows, in curb 6 inches from wall; aluminum tablet stamped " 67 "

Brunswick, left of main entrance to city hall, in wall; aluminum tablet stamped " 70 ".

Brunswick, south side of Union Station, in doorstep leading to basement;

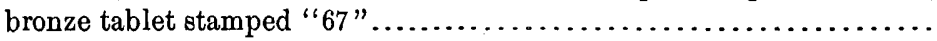

SEBAGO QUADRANGLE.

SEbago, aloNg maINe Central RaIlRoad, to poINT 2.1 miles NORThWest of mattocks.

Sebago, in front of station; top of rail

Sebago Lake, 0.3 mile northwest of, right side of track, in rock ledge; aluminum tablet stamped " 287 ".

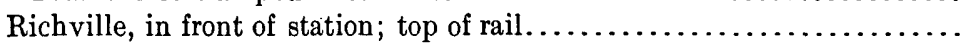

Richville, 0.6 mile northwest of, right side of track, in rock; aluminum tablet stamped " 293 ".

Steep Falls, in front of station; top of rail

Steep Falls, 0.2 mile northwest of, right side of track, in rock; aluminum tablet.

Mattocks, in front of station; top of rail.

Mattocks, 2.1 miles northwest of, right side of track, in rock; aluminum tablet stamped " 320 "

KEZAR FALLS QUADRANGLE.

CORNISH, WEST ALONG HIGHWAYS TO 1.2 MILES WEST OF PORTER.

Cornish, at forks of Maine and Cumberland streets, on right side going east, in side yard of dwelling, in rock; aluminum tablet stamped " 347 ".....

Kezar Falls, northeast of bridge, in Hollem's lot, 60 feet from road, 12 feet east of west fence, in rock; aluminum tablet stamped " 381 "..........

Porter, 1.2 miles west of, north side of road, in rock; aluminum tablet stamped " 399 ".

\section{PRIMARY LEVELING.}

Anson, Augusta, Bingham, Brassua Lake, Moosehead Lake, Norridgewock, Skowhegan, The Forks, Vassalboro, and Waterville quadrangles.

Kennebec, somerset, and Piscataquis countes.

The elevations in the following list are based on tidal records of the Coast and Geodetic Survey at Portland. The work was previously based on Augusta datum from tidal records of the Coast and Geodetic Survey at Hallowell; but the results of a double- 
rodded line run in 1905 by the water-resources branch of the United States Geological Survey from Augusta to Brunswick, checking upon the Coast and Geodetic Survey gage bench marks at Abagadassett Point and Pleasant Point with a connection also at Moosehead from Penobscot River levels, showed considerable error. A line of precise levels was therefore run from Portland (where a more reliable sea-level value could be obtained) to Brunswick, from which was derived a correction of 2.651 feet to be added to the original unpublished values of the water-resources branch and 2.593 to be added to the original unpublished elevations of the bench marks on Augusta datum from Augusta to Moosehead. The closures upon Coast and Geodetic Survey gage bench marks by the water-resources branch line corrected to Portland datum are as follows: At Point Pleasant, + 1.11 feet; at Abagadassett Point, +0.41 feet; at Hallowell bench mark $2,+2.651$ feet; at Augusta, +4.608 feet.

A small discrepancy with levels brought by the topographic branch from Bangor up the Penobscot River, in 1904, to Norcross and thence by wye and water levels in the four succeeding years by the water-resources branch to Moosehead, has been adjusted into leveling of the water-resources branch.

The leveling was done in 1903 and 1904 by F. J. McMaugh.

$$
\text { AUGUSTA QUADRANGLE. }
$$

HALLOWELl, NORTH ALONG MAINE' CENTRAL RAILROAD, to AUGUSTa.

Hallowell, on south face of stone snubbing post of Granite Company's wharf; horizontal chisel mark $a$ (Coast and Geodetic Survey bench mark No. 1) .......................................

Hallowell, Water street (southeast) còrner of cotton mill; horizontal chisel mark (Coast and Geodetic Survey bench mark No. 2; discarded elevation by Coast and Geodetic Survey equals 24.44 feet above mean water level)

Feet.

13. 804.

Augusta, at northwest corner of west wing of state house; aluminum tablet stamped (reestablished in 1909 by the water-resources branch).........

Augusta, in the upper and outer stone on top of the small ornamental tower, on the southwest corner of river wall around the arsenal; drilled hole $b$

\section{...}

\section{VASSALBORO QUADRANGLE.}

AUGUSTA, NORTh ALONG MAINE CENTRAL RAILROAD, to VASSALboro.

Augusta, 4 miles northeast of, 865 feet north of milestone "66 and 185," in south granite abutment of railroad culvert; aluminum tablet stamped "34 AUGUSTA"

Vassalboro, 4.5 miles south of, at sawmill, on top of stone culvert; chisel mark.

$a$ This bench mark is assumed to have settled 0.344 foot, as found by checked connection with bench mark No. 2. Discarded elevation by Coast and Geodetic Survey equals 11.50 above mean water level. $\checkmark$ Elevation by the water-resources branch, United States Geological Survey, exact point of Coast and Geodetic Survey bench mark impossible to determine; discarded elevation by Coast and Geodetíc Survey equals 16.56 above mean water. 
Vassalboro, stone culvert near milestone "73 and 183," Portland and Vanceboro, in southeast corner; aluminum tablet stamped "39 AUGUSTA"...

Vassalboro, in front of station; top of rail.

\section{WATERVILLE QUADRANGLE.}

VASSALBORO, NORTH ALONG MAINE CENTRAL RALROAD, TO GOODWILL.

Winslow, 0.5 mile south of, 5.5 miles north of Vassalboro, in east abutment of new bridge over Kennebec River; aluminum tablet stamped " 53 AUGUSTA".

Winslow, in front of station; top of rail

Waterville, west side of canal, on grounds of Hollingsworth. \& Whitney, in stone wall; brass cap.

Waterville, east bank of river, 30 feet south of dam, 140 feet north of railroad bridge, in ledge marked "Top of flash boards;" copper bolt.....

Shawmut, in west wall of engine house of the Lawrence Newhall plant; aluminum tablet stamped "113 AUGUSTA" ......................

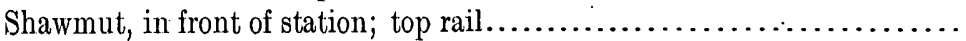

Goodwill farm, in front of station; top of rail.......................

Hinckley, in front of station; top of rail.

Goodwill, 1.8 miles north of, in milestone "7 miles to Skowhegan, 95 miles to Portland;" aluminum tablet stamped "126 AUGUSTA".....

\section{SKOWHEGAN QUADRANGLE.}

AT SKOWHEGAN.

Skowhegan, in front of station; top of rail

Skowhegan, in corner of high school building, on island; aluminum tablet stamped "172 AUGUSTA." (Reported as having the end defaced)....

Skowhegan, 0.3 mile south of station, on coping stone at west end of south abutment of railroad bridge; aluminum tablet stamped " 176 AUGUSTA"

178. 897

\section{NORRIDGEWOCK QUADRANGLE.}

SKOWHEGAN, SOUTHWEST ALONG SKOWHEGAN AND NORRIDGEWOCK ELECTRIC RAILROAD, TO NORRIDGEWOCK.

Norridgewock, in northeast corner of hotel; aluminum tablet stamped "199

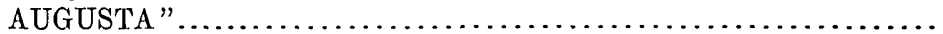

Norridgewock, in front of station; top of rail

\section{ANSON QUADRANGLE.}

NORRIDGEWOCK, NORTH ALONG SOMERSET RAILWAY, TO ANSON.

Madison, in center of town, in underpinning of Odd Fellows block; aluminum tablet stamped "294 AUGUSTA".......................

Anson, in front of station; top of rail........................... 297.035 263.4

MADISON, EAST TO MADISON CENTER; THENCE NORTH VIA NORTH MADISON, TO SOLON.

Madison Center, at entrance to Lakewood Park (property of Somerset Traction Company), at forks of road, in granite foundation of farmhouse; bronze tablet stamped "363 AUGUSTA" .......................

North Madison, 540 feet south of first four of "Twelve Corners," on summit of small hill, west side of road, in flint ledge; bronze tablet stamped "622 AUGUSTA".

Solon, New Caratunk Hotel (J. H. Grey, owner), in granite underpinning of west corner; bronze tablet stamped "403 AUGUSTA". 
SOLON, WEST ALONG PUBLIC ROADS, TO EMBDEN CENTER.

Embden Center, at three corners of road, in front of old house, east side of road; bronze tablet stamped " 474 AUGUSTA" ...................

EMBDEN CENTER, SOUTH ALONG PUBLIC ROAD VIA NORTH ANSON, TO ANSON.

North Anson, opposite road forks, in east face of southeast corner of granite underpinning of building owned by F. W. Bunker; aluminum tablet stamped " 293 AUGUSTA" ..................................

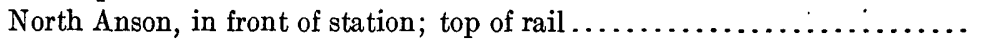
315.4

\section{BINGHAM QUADRANGLE.}

SOLON, NORTH ALONG SOMERSET RAILWAY, TO BINGHAM.

Bingham, 3 miles south of, 7 miles north of Solon, right side of road, in bowlder; bronze tablet stamped "376 AUGUSTA"

Bingham, south end of east abutment of bridge over Austin Stream, bronze tablet stamped " 367 AUGUSTA" ............................. Bingham, in front of station; top of rail.

BINGHAM, NORTH ALONG HIGHWAY, TO CARATUNK.

Bingham, 6.5 miles north of, in southeast corner of George Gordon's house; bronze tablet stamped " 434 AUGUSTA"

Briggs Ferry, 600 feet north of (10.6 miles north of Bingham), ledge of rocks right side of road; bronze tablet stamped "451 AUGUSTA" ..........

Caratunk, 1,000 feet sou th of post-office, right of road, in rock ledge; bronze tablet stamped "588 AUGUSTA".

BiNGHAM, NORTHEAST ALONG SOMERSET RAILWAY, TO AUSTIN POND AND MOXIE POND.

Bingham, 5 miles northeast of, in rock wall at Chamberlain Hill; aluminum tablet stamped "1324 AUGUSTA" (bench mark on old line was unre-

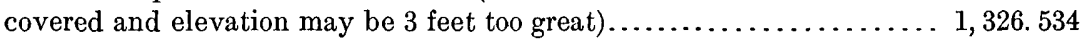

Deadwater station, 3.7 feet east of southwest corner of tank house in granite underpinning; aluminum tablet stamped "1001 AUGUSTA" ........ 1, 003.500

Austin Pond, 100 feet east of main camp, 40 feet south of road to pond, in bowlder; aluminum tablet stamped "1190 AUGUSTA"............ 1, 192. 464

THE FORKS QUADRANGLE.

CARRITUNK, NORTI ALONG ROAD VIA THE FORKS, TO INDIAN POND.

The Forks, 2.5 miles south of, 5.2 miles north of Carritunk, 2,000 feet north of Ed. Morris's house, east side of road, in ledge of rocks; aluminum tablet stamped "576 AUGUSTA"

579.066

The Forks, east of bridge over Kennebec River, in granite abutment; bolt.

The Forks, 3 miles north of, west side of river, 300 feet south of Cold Stream, in rock ledge; aluminum tablet stamped "611 AUGUSTA"...........

The Forks, 10.2 miles north of, north bank of Chase Stream at mouth, in rock ledge; aluminum tablet stamped " 757 AUGUSTA".............

Indian Pond, east bank of river near southeast corner of dam, in rock ledge; aluminum tablet stamped " 933 AUGUSTA" ................

760.062

936. 013

THE FORKS, EAST TO LOWER (NORTH) END OF MOXIE POND; THENCE BY WATER LEVELS TO UPPER END.

The Forks, 3 miles east of, 320 feet east of Ed. Croto's house, south side of road, in large bowlder; aluminum tablet stamped "901 AUGUSTA"... 
Moxie Pond, north end of, at upper dam, in ledge at east side of Moxie Stream, 90 feet northeast of sluice gate; aluminum tablet stamped " 959 AUGUSTA"

Moxie Pond, on west bank of Baker Stream, 50 feet east of railroad location, in ledge; aluminum tablet stamped "963 AUGUSTA" .............

966.060

\section{BRASSUA LAKE QUADRANGLE.}

INDIAN LAKE, NORTHEAST ALONG NORTH SIDE OF INDINN POND, TO MOOSEHEAD.

Marrs Camp, north end of Indian Pond, 6.1 miles north of dam, at side of road, in rock ledge; aluminum tablet stamped "946 AUGUSTA".....

\section{MOOSEHEAD LAKE QUADRANGLE.}

AT MOOSEHEAD.

Moosehead, southeast corner of east abutment of Canadian Pacific Railway bridge over east outlet of Moosehead Lake; aluminum tablet $a$ stamped "1026 AUGUSTA"................................ 1, 028. 154

Moosehead Lake, low water of October, 1903; surface.............. 1, 022.0

Moosehead Lake; high water (from information by proprietor of Outlet House $) \ldots \ldots \ldots \ldots \ldots \ldots \ldots \ldots \ldots \ldots \ldots \ldots \ldots \ldots \ldots \ldots \ldots \ldots \ldots \ldots \ldots \ldots \ldots \ldots, 1,028.7$

Buckfield, Lewiston, Livermore, Norway, and Poland quadrangles.

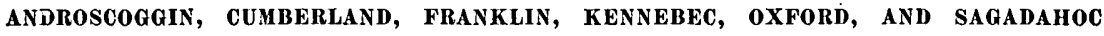
COUNTIES.

The elevations in the following list are based on bench marks of the double-rodded line of the Androscoggin River survey (water-resources branch United States Geological Survey), corrected in accord with - the precise-level line of the topographic branch from Portland to Brunswick; and such of those bench marks as come in these quadrangles are included in the list.

The leveling was done in 1905 and 1906 by F.J. McMaugh.

LEWISTON QUADRANGLE.

LISBON FALLS, NORTHWEST ALONG MANNE CENTRAL RAILROAD, tO LEWISTON; THENCE NORTH TO KEENS MILLS. $b$

Lisbon Falls, in ledge about " $10 \frac{1}{2}$ miles to Lewiston," side of river opposite lower end of Frosts Park; aluminum tablet (permanent bench mark No. 7)

Feet.

111. 231

Dingley farm, in large bowlder near north line, east of road about 300 feet; aluminum tablet (permanent bench mark No. 9) .................

Babbett \& Googin dam, in high point of ledge below (this ledge is in bed of river and is an island during high water); aluminum tablet (permanent bench mark No. 10)

LEWISTON, NORTHEAST ALONG MAINE CENTRAL RAILROAD, TO LEEDS JUNCTION; THENCE SOUTH ALONG MAINE CENTRAL RAILROAD TO LISBON.

Lewiston, in south wall 50 feet north of west end of dam No. 4, Union Waterworks Company; point " $\mathrm{S}$ "

Lewiston, near end of railroad bridge over canal, southwest corner of Bates cotton mill, on foundation.

148. 400

\footnotetext{
$a$ Elevation as brought by careful wye and water levels from Bangor, 1,028.223-a closure of 0.069, which can be thrown to water levels and the Penobscot and these corrected Kennebec levels from Portland can be considered as adjusted.,

$\checkmark$ Bench marks by water-resources branch.
} 
Lewiston, in south face of southwest corner of post-office building; aluminum tablet stamped "AUGUSTA 196".

Lewiston, opposite baggage room at upper station; north rail.

Lewiston, 2.8 miles north of, west side of track, in milestone "V 215;" aluminum tablet stamped "AUGUSTA 228 ".......................

Lewiston, 5.8 miles north of, in milestone "V 212;" aluminum tablet stamped "AUGUSTA 275 ".

Feet.

196. 000

205. 1

227.852

275.312

Greene, in front of station; top of rail.

302. 0

Greene, 0.25 mile north of, in ledge; aluminum tablet stamped " 293 AUGUSTA"

Leeds, in front of station; top of west rail

292. 611

Leeds, 0.25 mile south of, in milestone "V 207;" aluminum tablet stamped "AUGUSTA 281".

Wales, in front of station, at crossing; top of rail

271. 2

Leeds Junction, 3 miles south of, in east face of south wall of stone, culvert; aluminum tablet stamped "AUGUSTA 254 ".

281. 194

255.4

Sabattus, 330 feet east of station, north of track, in large bowlder; aluminum tablet sțamped "AUGUSTA 266 ".

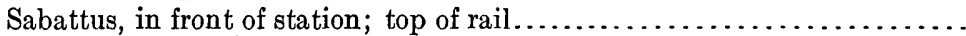

Webster woolen mills, Sabattus River; top of dam....................

Crowleys Junction, south end of west abutment......................

Crowleys Junction, north end, east abutment of railroad bridge; aluminum tablet stamped "189 AUGUSTA".

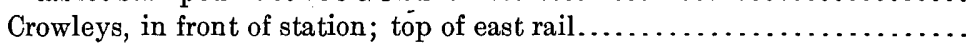

Crowleys, 1.2 miles from junction, east wall, south end of granite abutment; at Moody Brook.

Lisbon, in front of station; top of east rail.

Lisbon, in front of office building of Farwell mills, 9 feet from northwest corner, 160 feet from junction of Main and Farwell streets; aluminum tablet stamped "185 AUGUSTA".

253. 925

265.797

262.3

215.8

188. 324

189. 108

191. 2

186. 683

199.8

184. 801

LEWISTON, SOUTHWEST ALONG THE GRAND TRUNK RAILWAY AND THE MAINE CENTRAL RALLROAD, TO RUMFORD JUNCTION.

Auburn, main track of Grand Trunk Railway; top of south rail........... Rumford Junction, east of track, in milestone "Portland 32 miles, Vanceboro 221 miles;" aluminum tablet stamped "205 AUGUSTA"........

RUMFORD JUNCTION, WEST TO POLAND; THENCE NORTH TO BUCKFIELD.

Lewiston Junction, 1 mile north of, north end of east abutment of Maine Central Railroad bridge; aluminum tablet stamped "280 AUGUSTA"..

Elmwood Farm station; top of east rail .........................

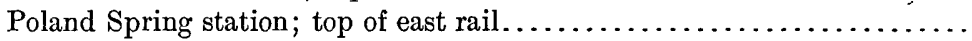

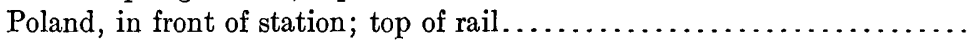

Poland, 1.7 miles north of station, 475 feet south of milepost, in west end of south wall of culvert; aluminum tablet stamped "284 AUGUSTA".....

Mechanic Falls, in front of Maine Central Railroad station; top of west rail.

Mechanic Falls, 1 mile north of, 420 feet north of railroad crossing, west end of south abutment of Maine Central Railroad bridge over Bog Brook; aluminum tablet stamped " 267 AUGUSTA"...................

West Minot, main track in front of station; top of west rail..............

West Minot, 250 feet north of station, 50 feet south of highway bridge, 80 feet west of track, in rock ledge; aluminum tablet stamped " 334 AUGUSTA". 
East Hebron, 875 feet north of railroad crossing at station, 75 feet west of railroad track, in large bowlder; alluminum tablet stamped " 348 "......

Feet. 347.889

POLAND, SOUTHWEST TO WEST POLAND; THENCE NORTH VIA WATER LEVELING TO OXFORD; THENCE NORTH 3.6 MILES.

Poland, 2.2 miles from, 18 feet south of road and 750 feet east of road on east side of Tripp Pond; aluminum tablet stamped " 343 "..............

Tripp Pond, July 7, 1906, 11.30 a. m.; surface of water...............

West Poland, 1 mile west of, large bowlder 70 feet west of bridge over Potash Brook, 25 feet north of road, 360 feet west of house owned by G. D.

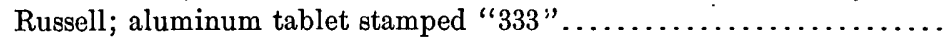

Thompson Lake, July 9, 1906, 3.25 p. m.; surface of water............

Oxford, ledge on Walker property, 100 feet west of northwest corner of school, 15 feet west of fence, 350 feet northwest of hotel; aluminum tablet stamped " 348 ".

Oxford, 3.6 miles north of, 500 feet north of Gilman's crossing, 280 feet east of highway, on property of A. 0 . Lovering; aluminum tablet stamped "363".

332.977

324. 7

348.340

363. 348

SOUTH PARIS, EAST 5 MILES ALONG ROAD TO BUCKFIELD.

South Paris, 2.1 miles east of, west bank of Stony Brook, 25 feet north of bridge and 85 feet northeast of road forks, in ledge; aluminum tablet stamped " 479 ".

South Paris, 4.9 miles east of, east of road, in pasture, and 130 feet southeast of four corners, in ledge; aluminum tablet stamped " 1015 ".

Hebron, 40 feet southeast of corner of $H$. T. Glove livery barn, 60 feet northeast of center of highway, in rock ledge; aluminum tablet stamped " 576 "

\section{NORWAY QUADRANGLE.}

POINT 3.6 MILES NORTH OF OXFORD, NORTHWEST ALONG GRAND TRUNK RAILWAY, TO SOUTH PARIS.

South Paris, 1.4 miles south of, south end of east wall of granite arch culvert;

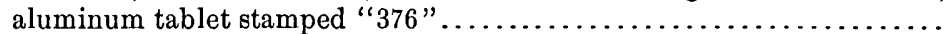

South Paris, in front of station; top of west rail................... 392.2

\section{BUCKFIELD QUADRANGLE.}

PONNT 5 MILES EAST OF SOUTH PARIS, NORTHEAST TO BUCKFIELD; THENCE EAST TO TURNER.

Buckfield, 2.6 miles west of, north side of road in angle of fence 330 feet west of house belonging to Greene Turner, in large bowlder; aluminum tablet stamped " 826 ".

Buckfield, in second course from top, at east end of south abutment of railroad bridge over Twentymile River; aluminum tablet stamped " 364 "..

Turner, top of coping at north end of dam, 2 feet south of face of retaining wall and 2.5 feet west of downstream face of dam; aluminum tablet stamped " 303 ".

LIVERMORE QUADRANGLE.

TURNER, NORTHEAST TO KEENS MILLS

Keenes Mills Cemetery, 0.25 mile north of, in orchard of Edward Pratt, 500 feet north of house, and 150 feet east of highway; aluminum tablet stamped " 283 " 
Bethel, Fryeburg, Kezar Falls, and Rumford quadrangles. CUMBERLAND, OXFORD, AND YORK COUNTIES.

The following elevations. were determined by primary leveling extended from Cornish and Porter, on the precise-level line from Portland, and are based upon mean sea level. The single line, Lynchville to Bethel, closes 2.319 feet high on Androscoggin levels of the water-resources branch, corrected for a 1-foot error found at Turner Bridge.

The leveling was done as follows: In all four quadrangles by C. K. Alexander in 1908; in Fryeburg and Kezar Falls quadrangles by E. B. Hillegass in 1909.

\section{KEZAR FALLS QUADRANGLE்.}

NEAR PORTER, NORTH ALONG HIGHWAYS, TO FRYEBURG.

Porter, 1.2 miles west of, north side of road, in rock; aluminum tablet stamped " 399 ".

Feet.

Porter, 3.3 miles northwest of, at fork of roads, in large rock, southwest corner of forks; aluminum tablet stamped " $496 "$ ".................

Rands School, 6.5 miles northwest of Porter, west of road, opposite schoolhouse, in rock ledge; aluminum tablet stamped " 875 ".

398.873

495.815

Brownfield station, 3.8 miles southwest of, in large rock north of road; aluminum tablet stamped " $515 "$ "..........................

Brownfield, 3 miles west of station, at southeast corner of road crossing, on granite post; paint mark " 481.6 "

875.374

Fryeburg, 3.9 miles south of, on west side of road, in large rock; aluminum

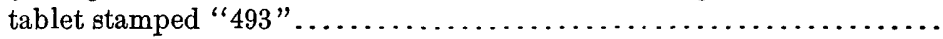

493. 458

CORNISH, NORTHWEST ALONG MAINE CENTRAL RAILROAD, TO FRYEBURG (MEAN OF TWO RUNNINGS).

Cornish station, on Maine Central Railroad; spike in east end of crossing planks, marked " 300 ".

299.98

West Baldwin, 600 feet east of station; spike in east end of railroadcrossing planks, marked " 346 ".

Bridgton Junction, 1 mile southeast of, at northeast side of railroad, in top face of culvert stone; aluminum tablet stamped " 356 ".

355.538

Hiram, 2 miles west of, south side of railroad, in top face of southeast abutment of small bridge; aluminum tablet stamped " 398 ".

396. 596

East Brownfield (Brownfield station), at southeast corner of station, in top face of large embedded rock; aluminum tablet stamped " 400 ".

East Brownfield (Brownfield station), 3 miles northwest of, at crossing of brook, in top face of south side of east abutment of bridge; aluminum

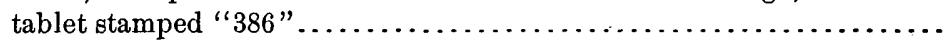

\section{FRYEBURG QUADRANGLE.}

FRYEBURG, NORTHEAST ALONG HIGHWAYS, TO WEST BRIDGTON; THENCE NORTHWEST TO LOVELL.

Fryeburg, at corner of Main and Portland streets, in east face of monument; aluminum tablet stamped " $429 "$ "........................

Fryeburg, 2.7 miles northeast of, south of road in large rock; aluminum

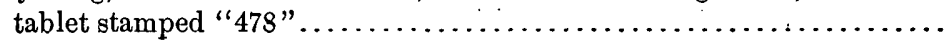

478.300 
East Fryeburg, at northeast corner of road crossing, in southwest corner of Mount Pleasant Band hall; aluminum tablet stamped " 486 ".

West Bridgton, in southwest corner of schoolhouse, north of road; aluminum tablet stamped " 516 ".

Lovell, 2.9 miles southeast of, in southeast corner of Black Mountain schoolhouse; aluminum tablet stamped " 549 ". in rock of stone wall; aluminum tablet stamped " 439 "

LOVELL, NORTHEAST AND NORTH ALONG HIGHWAYS, TO LYNCHVILLE.

Sweden Corner, at northwest corner of road crossing, in southeast corner of stone wall of O. P. Saunders's residence; aluminum tablet stamped "692".

East Sweden, in southeast corner of stone wall of schoolhouse; aluminum o tablet stamped " 568 ".

North Waterford, 4 miles south of, in southeast corner of stone wall of schoolhouse; aluminum tablet stamped " 963 "

963. 723

North Waterford, 2.7 miles southeast of, west of road, opposite John Tubb's residence, in large rock; aluminum tablet stamped " 797 "

797.533

North Waterford, in stone wall at northwest corner of Congregational Church; aluminum tablet stamped " 650 "

Lynchville, on foundation stone on north side at east end of bridge over Crooked River; paint mark " 555.7 "

554. 122

FRYEBURG, NORTH ALONG HIGHWAYS, TO NORTH FRYEBURG; THENCE EAST TO IOVELI, THENCE NORTH TO EAST STONEHAM.

Fryeburg Center, opposite Odd Fellows' hall, in face of large bowlder at northwest corner of road forks; aluminum tablet stamped " 438 ".

North Fryeburg, in top face of door stone of Universalist Chapel; aluminum tablet stamped " 388 ".

North Fryeburg; at northwest corner of Harry Hutchin's general store, on

- top of stone post; chisel mark" " $387 "$ "............................

Harbor, at Iron Bridge, in top face of stone of northwest abutment; aluminum tablet stamped " 381 ".

Lovell, 0.2 mile north of road forks, in front of $\mathrm{C}$. $\mathrm{K}$. Chapman's residence, in rock of stone wall; aluminum tablet stamped " 440 "

Center Lovell, 300 feet south of schoolhouse, east of road, in top face of large bowlder; aluminum tablet stamped " 530 "...................

Center Lovell, 4 miles north of, in front of Stephen Kimball's residence, west of road, in top face of bowlder embedded in ground; aluminum tablet stamped " 725 "

East Stoneham, opposite to Knights of Pythias hall, in large bowlder; aluminum tablet stamped " 629 "

HARBOR, NORTHWEST ALONG HIGHWAY 2.8 MLLES (SINGLE-SPUR LINE).

Harbor, 2.8 miles northwest of, west of road opposite O. P. Stevens's residence, in rock; aluminum tablet stamped " 423 "

423.187

53131-Bull. 437-10--2 


\section{BETHEL QUADRANGLE.}

LYNCHVILLE, NORTH ALONG HIGHWAY, TO BETHEL.a

Lynchville, 2.5 miles north of, 275 feet north of bridge over Crooked River, Feet. in rock ledge at west side of road; aluminum tablet stamped " 577 "..... Albany, 1.3 miles north of, on rock at northwest corner of road forks; paint mark "654.6".

Sango Pond, near south end of, west of road, in top face of large bowlder; aluminum tablet stamped " 667 ".

Bethel, at foot of Mill Hill, on rock at northeast corner of street; chisel mark " 659 ".

North Bethel, 3 miles south of, between Bethel and Maysville, in west end of south abutment of covered highway bridge over Androscoggin River; aluminum tablet (water-resources branch bench mark No. 27) ...........

RUMFORD QUADRANGLE,

LYNCHVILLE, NORTH ALONG HIGHWAY, TO BETHEL.a

Albany, 0.8 mile south of town house, west of road, near Carter Grover's residence, in rock ledge; aluminum tablet stamped " 647 "........... Albany Corners or Town House, on rock at southwest corner of crossroads; chisel mark " $651 "$

\section{Belfast, Castine, and Rockland quadrangles.}

\section{KNOX AND WALDO COUNTIES.}

The elevations in the following list are based on an aluminum tablet in the post-office and custom-house building at Bangor, the elevation of which is accepted as 23.725 feet above mean sea level, as derived from a tide gage at Bucksport.

The leveling of this list was begun at a bench mark at North Searsport, described in another list republished from Bulletin 185 (p. 20), and was double rodded to West Rockport. The leveling was done in 1904 by F. J. McMaugh.

BELFAST QUADRANGLE.

SW'ANVILLE, SOUTH ALONG HIGHWAY, TO BELFAST.

Swanville, 3 miles south of, in granite ledge at left of road; aluminum tablet stamped " 216 "

Feet. 215. 852

Belfast, in water table on Church street front of court-house; aluminum tablet stamped "102".

DUCKTRAP RIVER, SOUTHWEST ALONG HIGHWAY VIA LINCOLN, TO CAMDEN.

Northport, 4.1 miles south of, 100 feet south of L. D. Ames's house, 65 feet west of road; aluminum tablet stamped " 34 ".

Lincolnville Beach, north end of bridge over inlet; mark on stone coping. Lincolnville, 2.4 miles south of, in ledge at top of hill, 25 feet south of wood road west, 600 feet south of house; aluminum tablet stamped " 194 "....

a Portion of a line closing 2,319 feet high upon Androșcoggin levels of water-resources branch corrected for a 1-foot errọ found at Tựner Bridge. 
CASTINE QUADRANGLE.

BELPAST, SOUTH ALONG HIGHWY, TO DUCKTR $\mathbf{P}$ RIVER.

Belfast, 2.5 miles south of court-house, coping top of dam at Little River pumping station.

Feet,

22. 7

50.065

at left of road, on ledge; aluminum tablet stamped " 50 ". . . . . . . . . .

Northport, Saturday Cove, at junction of roads, 15.5 feet southwest of pump, 35 feet northeast of northeast corner of drab-colored building, in ledge; aluminum tablet stamped " $120 "$ "......................

119. 789

ROCKLAND QUADRANGLE.

CAMDEN, SOUTHWEST TO WEST ROCKPORT.

Camden, Camden National Bank, in granite pier, Elm street front; aluminum tablet stamped " 36 ".

220. 28

West Rockport, 2 feet west of signboard; mark on stone monument.......

West Rockport, in large bowlder southeast side of road to Warren, 500 feet southwest of signboard, 100 feet southwest of house, 25 feet east of center of road; aluminum tablet stamped " 228 "

227. 980

WEST ROCKPORT, SOUTH ALONG HIGHWAY, TO ROCKLAND; THENCE SOUTHWEST TO THOMASTON; THENCE NORTHWEST TO WARREN; THENCE NORTHEAST TO WEST ROCKPORT.

Rockland, 3.8 miles north of, in ledge west of road along west shore of Chickawaukie Pond, 80 feet south of telephone pole marked "U.S." with arrow pointing toward tablet; aluminum tablet stamped " 142 "....

Rockland, in water table at south side of post-office building near southwest corner; aluminum tablet stamped " 35 ".

Thomaston, 110 feet south of Main street and 45 feet south of end of iron fence on west side of warden's yard at state prison; mark on top of granite

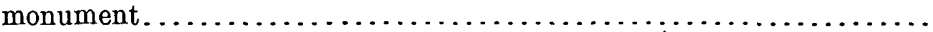

Thomaston, in first course of west pier of old gateway dated "1824" in wall of state prison grounds, opposite fire station house; aluminum tablet stamped " 142 ".

Warren, 0.2 mile south of road forks near; in ledge at left of road; aluminum tablet stamped " 131 ".

Warren, 3.9 miles northeast of, in ledge at junction of roads 50 feet south of main road; aluminum tablet stamped " $219 "$ "....................

218. 887

- Bangor, Bluehill, Bucksport, Ellsworth, Mount Desert, Orland, and Orono quadrangles.

HANCOCK, PENOBSCOT, AND WALDO COUNTIES.

The elevations in the following list are based on an aluminum tablet in the post-office and custom-house building at Bangor, stamped " 23 BANGOR 1899," the elevation of which is accepted as 23.725 feet above mean sea level, as determined by an adjusted circuit from Bucksport, where tidal observations on the Penobscot River were taken during two lunar months in August and September, 1899. The standard bench marks in this area, which were published in Bulletin No. 185, are included in this list. 
The leveling was done as follows: In Bucksport quadrangle by Robert Coe and J. W. Edgerly in 1899, and by F. J. McMaugh in 1904; in Bangor quadrangle by J. W. Edgerly in 1900; in Orono quadrangle by J. W. Edgerly in 1900, and by F. J. McMaugh in 1904; in Orland quadrangle by Robert Coe in 1899, and by A. S. Havens in 1901; in Bluehill and Mount Desert quadrangles by A. S. Havens in 1901; and in Ellsworth quadrangle by C. K. Alexander in 1908.

\section{BUCKSPOR'T $\cdot$ QUADRANGLE.}

BANGOR, SOUTH ALONG BUCKSPORT BRANCH MAINE CENTRAL RAILROAD, TO BUCKSPORT.

South Orrington, in foundation of Methodist Church, in middle of south face of third stone from southwest corner; aluminum tablet stamped " 61 BANGOR $1899 "$

Feet.

North Bucksport, 0.7 mile south of, 8 feet southwest of milepost "Bucksport 6 miles, Portland 150 miles," point of gray bowlder; chisel mark...

Bucksport Center, 0.9 mile south of, 10 feet south of milepost "Bucksport 4 miles, Portland 152 miles," point of blue bowlder; chisel mark.......

Bucksport, on lowest step of side wall on left side of stone steps to Buck Memorial Library, in front face of coping; aluminum tablet stamped " 43 BANGOR 1899 ".

BUCKSPORT, WEST ALONG HIGHWAY VIA PROSPECT, TO NORTH SEARSPORT.

Prospect, 0.25 mile south of, residence of J. R. Killman, in south face of brick, second above foundation and third from southwest corner; aluminum tablet stamped "77 BANGOR 1899 ".

Prospect, 3 miles west of, 80 feet east of four corners crossroads on Browns Hill, north of road, on large gray bowlder; chisel mark............. North Searsport, near road forks, 20 feet southwest of signboards "Frankfort 7 miles, Belfast 10 miles, Swanville 3 miles," "Searsport 7 miles, Monroe 5 miles," in small gray bowlder; aluminum tablet stamped " 393 BANGOR 1899 "

NORTH SEARSPORT, NORTH ALONG HIGHWAY VIA WEST WINTERPORT, TO NORTH NEWBURG.

West Winterport, residence of J. W. Hobbs, in front face of top front doorstep; aluminum tablet stamped "162 BANGOR $1899 " . . . \ldots \ldots \ldots \ldots$. Ellingwoods Corner, 0.25 mile north of, brick residence of Stephen $\mathrm{L}$. Perkins, center of capstone of cellar window at south end; aluminum tablet stamped " 387 BANGOR 1899 "........................

NORTH SEARSPORT, SOUTHWEST ALONG HIGHWAY, TO SWANVILLE.

Swanville, 150 feet south of Nickerson \& Quinn's store, west of road, in bowlder; aluminum tablet stamped " $209 " . . \ldots \ldots \ldots \ldots . . . \ldots . . .$.

\section{BANGOR QUADRANGLE.}

NORTH NEWBURG, NORTHEAST, TO HERMON CENTER; THENCE EAST ALONG HIGHWAY TO BANGOR.

North Newburg, at crossroads, 90 feet west of signboards "Winterport 11 miles, Carmel 4 miles, Bangor 11 miles, North Dixmont 9 miles," in ledge; aluminum tablet stamped "180 BANGOR 1899 "..............

Bangor, at south end of post-office and custom-house, about middle of first course of stone above the top of landing steps; aluminum tablet stamped "23 BANGOR $1899 "$ 
HERMON CENTER, NORTHWEST ALONG HIGHWAY VLA LEVANT, TO SOUTH CORINTH; THENCE EAST TO OLDTOWN.

Snow Corner, 100 feet northeast of crossroads, south of highway, at rear of post-office, in root of fir tree; nail.

Feet.

168. 90

Levant, west face of southeast corner stone of underpinning of post-office; aluminum tablet stamped "143 BANGOR".

Kenduskeag, in front of residence of Dr. J. B. Benjamine, east of road, in root of 3-foot elm tree; nail.

South Corinth, west of road, about 1,600 feet north of crossroads, in ledge on Cushman Hill; bronze tablet stamped "296 BANGOR".

295.935

Fudson, in east face of underpinning on east side of Baptist Church; aluminum tablet stamped " 151 BANGOR"

151. 363

West Oldtown, 300 feet west of corner, 36 feet north of road, southeast face of large bowlder; bronze tablet stamped "126 BANGOR"

125.678

\section{ELLSWORTH QUADRANGLE.}

ELLSWORTH, NORTH ALONG MAINE CENTRAL RAILROAD AND HIGHWAY, TO TILDEN; THENCE EAST TO WALTHAM.

Ellsworth, in foundation of Ellsworth Trust Company's bank building; aluminum tablet stamped " 24 ".

Ellsworth Falls, 2.6 miles northwest of, on Mariaville road, 150 feet east of road in field, in top face of large bowlder; aluminum tablet stamped " $145 "$.

Lakewood, 0.1 mile south of road corner, 30 feet west of road, in rock ledge; aluminum tablet stamped " 181 ".

Lakewood, 3.1 miles north of, at forks of old and new roads, east of road, 100 feet south of corner, in top face of large bowlder; aluminum tablet

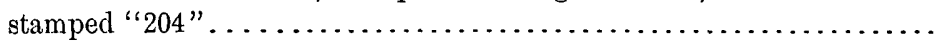

Tilden, at southeast corner of road forks, in top face of large bowlder; alumi-

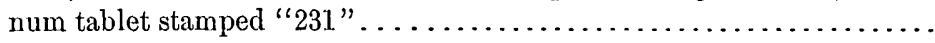

Waltham, 1 mile north of post-office, 0.1 mile west of crossroads, north of road, in top face of large bowlder; aluminum tablet stamped " 414 ".....

Waltham, at summit of hill, 250 feet north of graveyard, opposite schoolhouse, on north side of old cellar, in top face of buried rock; aluminum tablet stamped " 480 " (triangulation station) . . . . . . . . . . . . .

480.285

JLLSWORTI, EAST ALONG MAINE CENTRAL RAILROAD, TO FRANKLIN; THENCE NORTI AND WEST to waltham.

Washington Junction, 0.25 mile east of station, on south side of Washington County Railway, in top face of large bowlder; aluminum tablet stamped " 172 "

Washington Junction, 5 miles east of, at stream crossing known as "Stone Forse," south of railroad track in east end of abutment of railroad bridge; aluminum tablet stamped " 121 ".

Franklin, 1 mile west of, 250 feet north of railroad crossing, west of road, in top face of large bowlder; aluminum tablet stamped " 88 "..........

Eastbrook Corners, 3 miles south of, near crossing of outlet of Georges Pond, private road running west, west of road just south of road forks, in top face of large bowlder; aluminum tablet stamped " 168 "............

Eastbrook Corners, at southwest side of, in top face of large bowlder; aluminum tablet stamped " 169 " . . . . . . . . . . . . . . . . . . . . . .

WALThAM, SOUTHWEST TO A POINT 2 MILES NORTh OF ELLSWORTH FALLS.

Waltham, 1 mile south of post-office, 0.05 mile north of road forks, east of road, in top face of large bowlder; aluminum tablet stamped " 176 "... 
Waltham, 4 miles south of, near small summit (lower elevations toward south), in top face of large bowlder west of road; aluminum tablet stamped " 168 ".

Feet.

167. 787

Ellsworth Falls, 4.5 miles north of, on rock lying west of road; chisel mark "107".

106.41

Ellsworth Falls, 3.5 miles north of, at southwest corner of No. 8 plantation, 0.5 mile south of schoolhouse, east of road, in top face of large bowlder; aluminum tablet stamped " 125 ".

124. 555

ORONO QUADRANGLE.

MILFORD, NORTHEAST ALONG HUGHWA 7 MLLES (SPUR LINE).

Milford, 7 miles northeast of, near highway bridge over Birch Stream on Milford-Greenfield road, 80 feet south of center of and 28 feet east of center of traveled highway, in ledge; bronze tablet stamped " 130 BANGOR"

OLDTOWN, SOUTHWEST ALONG HGGWAY AND MAINE CENTRAL RAILROAD, to VEAZIE.

Oldtown, St. James Episcopal Church, corner Maine and Middle streets, east end of north face; aluminum tablet stamped "108 BANGOR"....

Orono, University of Maine, in west face of coping stone of Wingate hall; aluminum tablet stamped "115 BANGOR"..................

108. 106

VEAZIE, SOUTHEAST ALONG HIGHWAY, TO EAST EDDINGTON.

East Eddington, Universalist Church, in northwest corner stone; bronze tablet stamped "193 BANGOR"...........................

EAST EDDiNGTON to CLIFTON (SINGLE SPUR LINE).

Clifton, 9 feet east of southeast corner of Free Baptist Church, in ledge;

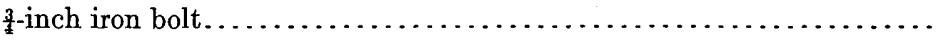

EAST EDDINGTON, SOUTH TO EAST HOLDEN; THENCE WEST ALONG MAINE CENTRAL RAILROAD, TO BANGOR.

Harts Corners, in east face of underpinning of Holden townhouse, 11 feet south of entrance; aluminum tablet stamped " 296 BANGOR".......

OLDTOWN, NORTh aLONG MAINE CENTRAL RAILROAD, to COSTIGAN.

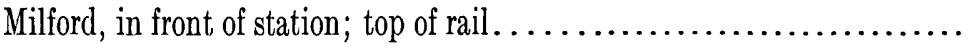

Oldtown, 3.1 miles north of, east side of track, in ledge; aluminum tablet

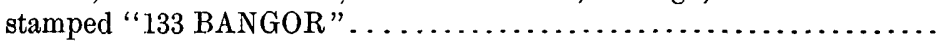

132.562

\section{ORLAND QUADRANGLE.}

BUCKSPORT, VIA ORLAND, EAST ORLAND, AND WEST ELLSWORTH, TO ELLSWORTH.

East Orland, 960 feet east of bridge at road forks, 70 feet to left of road, on side of bowlder; aluminum tablet stamped " 168 B 1899 "............

West Ellsworth, 1,150 feet west of road forks, 40 feet to left of road, bowlder in field; aluminum tablet stamped "275 BANGOR $1899 " . . . \ldots \ldots .$.

ELLSWORTH, NORTHWEST OVER WAGON ROAD, TO EAST HOLDEN.

Nicolin, 50 feet to left of Ellsworth-Bangor road and 10 feet to right of road from Nicolin railroad station to Branch Pond, on gray rock; aluminum tablet stamped "446 BANGOR".

Dedham, 1.5 miles south of Lake House railroad station, in west side of big bowlder; aluminum tablet $a$ stamped " 287 BANGOR". 
ORLAND, NORTH TO NEAR EAST BUCKSPORT (SINGLE SPUR LINE).

East Bucksport, 3 miles south of, northeast corner stone of East Bucksport Church; aluminum tablet stamped " 186 BANGOR"..............

BLUEHILL QUADRANGLE.

EAST ORLAND, SOUTHEAST ALONG HIGHWAY, TO BLUEHIL; THENCE NORTHEAST TO SURRY.

North Bluehill, 660 feet west of crossroads, 30 feet north of road running west, in bowlder; bronze tablet stamped "337 BANGOR 1901"........

Bluehill, 125 feet east of northwest-southeast road, 75 feet south of public wharf, in face of rock ledge; bronze tablet stamped "15 BANGOR 1901"..

Surry, 1.25 miles south of, 15 feet west of road, opposite house on right, about 250 feet south of road to left, in bowlder; chisel mark " $D$ "........... MOUNT DESERT QUADRANGLE.

FROM SURRY NORTHEAST TO ELLSWORTH.

Surry, 0.5 mile east of, 800 feet east of Surry townhall, 15 feet to right of road, in rock ledge; bronze tablet stamped " 88 BANGOR 1901 "......

\section{Lincoln, Mattawamkeag, Millinocket, Passadumkeag, and Winn quadrangles.}

\section{PENOBSCOT COUNTY.}

The elevations along Penobscot River in the following list are based on an aluminum tablet in the post-office and custom-house building at Bangor, stamped " 23 BANGOR 1899." The elevation of this bench mark is accepted as 23.725 feet above mean sea level. A double-rodded line was run, beginning at a bench mark at Oldtown, reported in another list (p. 22) republished from Bulletin 185. From Millinocket, water and spirit levels were extended by the Great Northern Paper Company and the water-resources branch of the United States Geological Survey to Moosehead, where a junction was made with the Kennebec levels. The extended ele- vations were found to be in such close agreement with the Kennebec levels, as corrected in 1906 to reliable mean sea-level datum at Portland, that no adjustment has been made in determining the elevations of this list.

The leveling was done in 1904 by F. J. McMaugh.

\section{PASSADUMKEAG QUADRANGLE.}

COSTíAAN, NORTH ALONG MAINE CENTRAL RAILROAD, TO ENFIELD.

Costigan, 215 feet north of station, railroad bridge, east end of south abutment; aluminum tablet stamped " 115 ".........................

Greenbush, 1.6 miles south of, in milestone marked "Vanceboro 93 miles, Portland 158 miles;" aluminum tablet stamped " 122 "..............

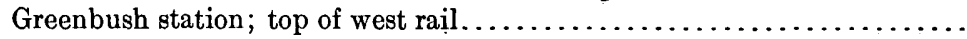

Greenbush, 1.4 miles north of, east side of track, in milestone marked "Vanceboro 90 miles, Portland 161 miles;" aluminum tablet stamped " $145 "$.

Feet.

114. 979

121. 999

133. 5

Olamon, in front of station; top of east rail..........................

Olamon, 0.7 mile north of, east side of track, in milestone marked "Vanceboro 87 miles, Portland 164 miles;" aluminum tablet stamped " 144 "... 
Passadumkeag, railroad bridge over Passadumkeag River, east end of south abutment; aluminum tablet stamped " 140 "

Feet.

Enfield, 1.9 miles south of, in milestone marked "Vanceboro 81 miles, Portland 170 miles;" aluminum tablet stamped " 185 ".

\section{IINCOLN QUADRANGLE.}

ENFIELD NORTHEAST ALONG MAINE CENTRAL RAILROAD, TO LINCOLN CENTER.

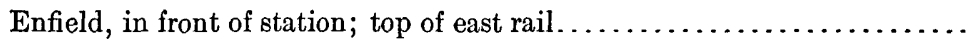

Enfield, 1 mile north of, in milestone marked "Vanceboro 78 miles, Portland 173 miles;" aluminum tablet stamped " 221 ".

South Lincoln, 1.1 miles southeast of, 4 miles north of Enfield, in milestone. marked "Vanceboro 75 miles, Portland 176 miles;" aluminum tablet stamped " 242 ".

South Lincoln, in front of station; top of rail.

South Lincoln, 1.9 miles northeast of, east side of track, in milestone marked "Vanceboro 72 miles, Portland 179 miles;" aluminum tablet stamped " 241 ".

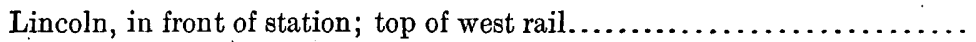

Lincoln, 0.7 mile north of, in milestone marked "Vanceboro 69 miles, Portland 182 miles;" aluminum tablet stamped " 223 "

\section{WINN QUADRANGLE.}

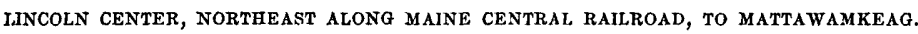

Lincoln Center, in front of station; top of east rail.

North Lincoln, in milestone marked "Vanceboro 66 miles, Portland 185 miles;" aluminum tablet stamped " 225 ".

North Lincoln, in front of station; top of east rail

North Lincoln, 3 miles northeast of, in milestone marked "Vanceboro 63 miles, Portland 188 miles;" aluminum tablet stamped " 229 ".........

Winn, 1.2 miles southwest of, in milestone marked "Vanceboro 60 miles, Portland 191 miles;". aluminum tablet stamped " $199 " . \ldots \ldots \ldots \ldots .$.

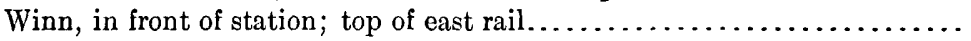

\section{MATTAWAMKEAG QUADRANGLE.}

MATTAWAMKEAG, NORTHWEST ALONG HIGHWAY, TO MEDWAY.

Mattawamkeag, in front of station; top of east rail.

Mattawamkeag, 0.2 mile north of, railroad bridge over Mattawamkeag River, east end of south abutment; aluminum tablet stamped " 213 "........

Mattawamkeag, 3.1 miles northwest of, east side of road to Jordan's mill, 260 feet north of junction with main road to Medway, large bowlder; aluminum tablet stamped " 217 ".

Mattawamkeag, 6.64 miles northwest of, west of road in clearing, 120 feet northeast of small shack, 160 feet east of log cabin, large bowlder; aluminum tablet stamped " 320 ".

Medway, 2.36 miles southeast of, west of road, 250 feet northwest of Clarke Lakeman's house, in ledge; aluminum tablet stamped ' 256 "......... 
MILIINOCKET QUADRANGLE.

MEDWAY, NORTHWEST AI.ONG HIGHWAY, TO MILLINOCKET; THENCE SOUTHWEST, ALONG BANGOR AND AROOSTOOK RAILROAD, TO TWIN LAKES.

Medway, 0.27 mile west of ferry, on land of A. T. Reed, 50 feet east of road and 120 feet west of his house, in ledge; aluminum tablet stamped " 279 ".

Medway, 5.30 miles northwest of, 745 feet north of Charles T. Powell's house, 35 feet west of road, in bowlder; aluminum tablet stamped " 306 "..

Millinocket Congregational Church, southeast corner of granite underpinning of tower; aluminum tablet stamped " 384 "..................

Millinocket, in front of station; top of south rail...................

Twin Lake dam (4.87 miles southwest of Millinocket), top of north pier at 24-foot gate opening; aluminum tablet stamped " 495 "...............

Twin Lake dam, 1 mile east of Norcross, 80 feet south of dam, south of track,

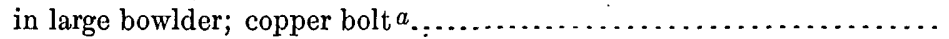

Feet.

278. 911

305.598

383. 992

363. 3

494. 562

503.43

\section{Cherryfield quadrangle.}

\section{WASHINGTON COUNTY.}

The elevations published in the following list are based on a bronze tablet at Millbridge, one-third mile southeast of post-office, in brown rock ledge on shore of harbor and 70 feet south of Sawyer's sardine wharf, stamped " 7 B 1901," the elevation of which is 7.247 feet above mean sea level, as determined by connection with tide gage at Millbridge upon which high and low water readings were made daily during a period of one lunar month in July and August; 1901. The standard bench marks depending on this datum are referred through sea-level connections to the central datum at Bangor and are stamped with the letter "B" in addition to the figures of elevation and year. The leveling was done in 1901 by A. S. Havens.

MILLBRIDGE, ALONG HIGHWAYS VIA STEUBEN AND UNIONVILLE, TO ChERRYFIELD.

Millbridge, at end of Sawyer's sardine wharf; 10 feet from southwest corner; ringbolt through stringpiece.

Feet.

Millbridge, 70 feet south of Sawyer's sardine wharf, in brown rock ledge on shore of harbor; bronze tablet stamped " 7 B 1901 " ..............

Millbridge, northeast corner of Main street and road to sardine wharf, on granite post; chisel mark.

Millbridge, southeast corner of Main street and Harrington road (signboard reads "Harrington 8 miles"), on granite post; chisel mark.

Steuben, at northwest corner of road intersection, on granite post (signboard reads "Gouldsboro 5 miles, Unionville 6 miles"); chisel mark....

Cherryfield, 0.1 mile south of station, in northwest corner of junction of east-west road (signboard reads "Franklin 18 miles, Harrington 6 miles"), in face of rock ledge; bronze tablet stamped "44 B 1901 ".............

a Used by Mr. Ferguson, of the Great Northern Paper Company, Millinocket, as basis of work in the vicinity of 'Twin Lakes. 
CHERRYFIELD, EAST TO HARRINGTON; THENCE NORTHEAST TO EPPING; THENCE WEST VIA SCHOODIC LAKE TO GREAT FALLS BRANCH SCHOODIC BROOK; THENCE SOUTHEAST TO CHERRYFIELD.

Harrington, 0.6 mile west of, at east end of new steel bridge over Harrington River, on south side of abutment; bronze tablet stamped "B 14 $1901 "$.

Feet.

14. 044

Epping, 1.25 miles west of, 60 feet west of crossroad from Columbia railroad station, 10 feet south of road, on bowlder; bronze tablet stamped " $226 \mathrm{~B}$ $1901 "$

226. 117

Epping, 3.5 miles west of, East Base Coast and Geodetic Survey base line station, on granite monument; bronze bolt. .....................

Cherryfield, 9.3 miles northwest of, on Denlois road, 1 mile southeast of road fork to Epping, 40 feet north of bridge over Great Falls Branch Schoodic Brook, 5 feet west of road, in face of large gray bowlder; bronze tablet stamped "151 B 1901 "...............................

151. 128
254. 187

\section{Cutler and Eastport quadrangles.}

WASHINGTON COUNTY.

The elevations in the following list depend on the height of a tidal bench mark described as "a hole drilled on Gun Rock, Lubec Channel," the height of which was determined by the United States Engineer Corps in 1878 from fifty-six consecutive day and night observations. $^{a}$

The circuit on Eastport quadrangle was closed through water levels between Eastport and Lubec.

The leveling was done in 1907 by H. M. Gilman.

$$
\text { EASTPORT QUADRANGLE. }
$$

LUBEC, SOUTHWEST ALONG HIGHWAYS, TO WHITING; THENCE NORTHWEST TO DENNYSVILLE; THENCE EAST VIA WEST PEMBROKE TO EASTPORT.

Lubec, Lubec Channel, in top of rounded rock, known as Gun Rock, in base of extremity of breakwater, established by United States Engineer Corps in 1878 (observations by Captain Trott, of Lubec); drill hole.....

Feet. 8. 291

Lubec, northeast of road, in southwest face of foundation of Disciples Church; aluminum tablet stamped " 118,1907 ".

118. 852

West Lubec, 1.2 miles east of, 500 feet west of small wooden bridge in hollow, 250 feet north of road, in rock ledge; aluminum tablet stamped " 45,1907 "

Whiting, 3.4 miles east of, 2 miles southwest of West Lubec, south edge of road, 250 feet south of John Craig's house, in rock ledge; aluminum tablet stamped " 96,1907 ".

Whiting, 0.3 mile east of road forks, 5 feet north of road at edge of stream in hollow, in top surface of rock ledge; aluminum tablet stamped " 20 ,

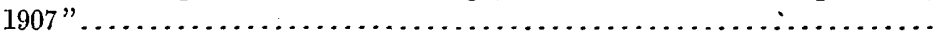

Whiting, 2.5 miles north of, 80 feet south of large iron bridge east of road in top of rock ledge; aluminum tablet stamped " 20,1907 ".

Dennysville, 3.5 miles south of, 30 feet west of road, 80 feet northeast of house at bend in road, in top face of rock ledge; aluminum tablet stamped " 147,1907 " 
Dennysville, 660 feet southeast of bridge over Dennys River, near top of hill by schoolhouse, in top face of rock ledge southwest of road; aluminum tablet stamped " 86,1907 ".

Dennysville, 3 miles north of, 3.2 miles southwest of Pembroke, opposite schoolhouse south of road, in rock ledge north of road; aluminum tablet stamped " 141,1907 "

West Pembroke, 100 feet north of Union League Church, south of road, in rock ledge; aluminum tablet stamped " 68,1907 " ................

Pembroke, 4 miles east of, 6.7 miles northwest of Eastport, 500 feet southeast of road forks, on opposite side of road from C. H. Leones' house, in top of rock ledge west of road; aluminum tablet stamped " 62,1907 " ........

Eastport, 3.5 miles northwest of, 500 feet east of toll bridge, in west end of stone watering trough at top of hill; aluminum tablet stamped " 62 , 1907 '"

141. 965

Eastport, corner of Washington and Water streets, in west face of southwest corner of granite belting course of custom-house and post-office; aluminum tablet stamped " 40,1907 "

\section{CUTLER QUADRANGLE.}

WEST LUBEC, SOUTHWEST ALONG HIGHWAYS TO CUTLER; THENCE NORTH to WHITING.

West Lubec, 3.2 miles south of, 500 feet west of stream crossing, in front of Stewart McFadden's house, 5 feet south of road, in rock ledge; aluminum

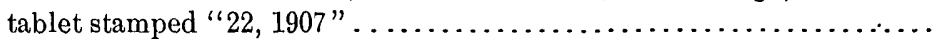

West Lubec, 6.3 miles southwest of, 7.5 miles northeast of Cutler, at end of $T$ road north, north side of road, in top of rock ledge; aluminum tablet stamped " 31,1907 "

Cutler, 3 miles northeast of, 110 feet north of road, 80 feet west of small house on hill, in rock ledge; aluminum tablet stamped " 136,1907 "......

Cutler, 600 feet west of road forks, north of road, in front of Samuel Maker's house, in top face of rock ledge; aluminum tablet stamped " 24,1907 "..

Cutler, 3.2 miles north of, 1,200 feet south of stream crossing, in top of large rock 5 feet west of road; aluminum tablet stamped " 156,1907 "........

Cutler, 6.5 miles north of, 4 miles south of Whiting, 0.4 mile north of Springbrook crossing, 10 feet west of road, in top face of rock; aluminum tablet stamped " 109,1907 ".

156.536

Augusta, Bath, Bethel, Buckfield, Dixfield, Freeport, Gardiner, Lewiston, Livermore, and Rumford quadrangles.

ANDROSCOGGIN, CUMBERLAND, FRANKLIN, KENNEBEC, OXFORD, AND SAGADAHOC COUNTIES.

The elevations in the following list of bench marks established by the water-resources branch of the United States Geological Survey under the general direction of $\mathrm{H}$. K. Barrows, district engineer, were determined by a double-rodded primary-level line extended from Augusta along the Maine Central Railroad to Brunswick; thence up Androscoggin River along railroad and highways to Errol, N. H. The New Hampshire elevations are not included in this list. The leveling was begun at a gage bench mark at Hallowell, Me., the stated elevation of which proved later to be unreliable. The elevations now given are based on mean sea level determined by-gage record at 
Portland, and accord with elevations determined by precise leveling of the topographic branch of the Geological Survey, from. Portland to Brunswick, as given in another list (pp. 8-9). At Turner Bridge, 39.7 miles from Brunswick, a 1-foot error was discovered by certain checked relevelings, and the remainder of the line was corrected by that amount; but there yet remains an outstanding discrepancy of 2.3 feet between this line and levels of the topographic branch at Bethel, an error that may be located by future work.

In running the base levels of 1905, from Hallowell via Brunswick to Livermore Falls, H. S. Boardman was chief of party. In running the base levels of 1906, from Livermore Falls to Errol, N. H., C. Robert Adams and T. W. Norcross were chiefs of party.

Primary leveling by the water-resources branch extended from Augusta.

FRoM AUgUSTA, SOUTHWEST ALONG MAINE CENTRAL RAILROAD AND HIGHWAY, TO BRUNSWICK (DOUBLE-RODDED LINE).

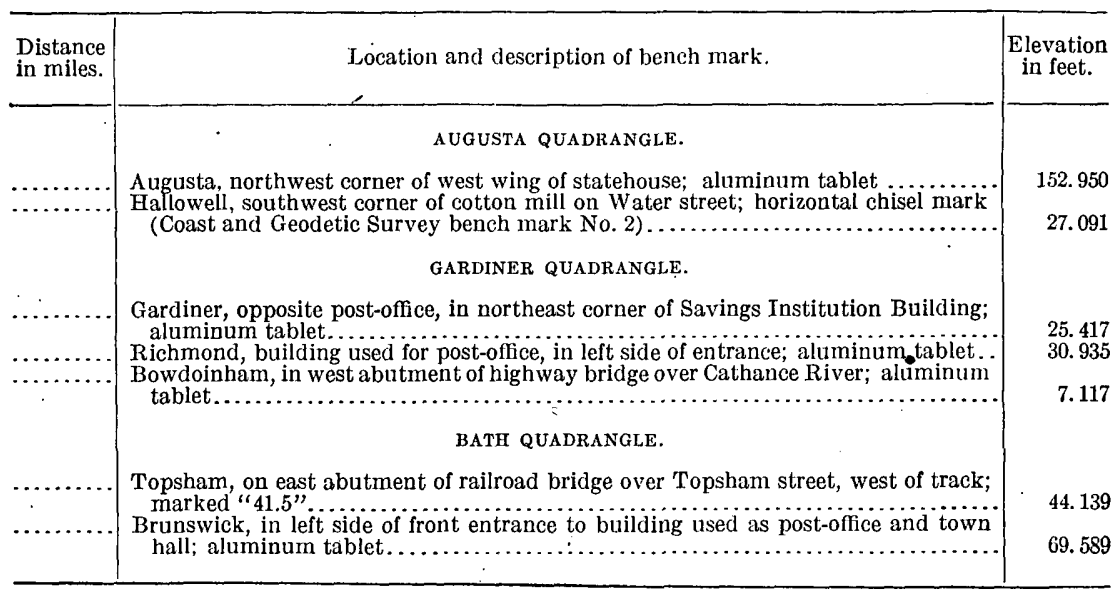


FROM BRUNSWICK, NORTH ALONG MAINE CENTRAL RAILROAD AND HIGHWAY, UP ANDROSCOGGIN RIVER.

\begin{tabular}{|c|c|}
\hline & FREEPORT QUADRANGLE. \\
\hline 3.1 & $\begin{array}{l}\text { Pejepscot, } 58.5 \text { feet south of center of track, } 00 \text { feet north of north end of railroad sta- } \\
\text { tion, in pasture belonging to Emory Barnes,.in ledge; aluminum tablet........ }\end{array}$ \\
\hline \multirow[t]{2}{*}{9.9} & 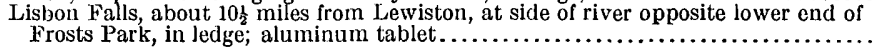 \\
\hline & LEWISTON QUADRANGLE. \\
\hline 14.0 & $\begin{array}{l}\text { Lewiston, } 6 \frac{1}{2} \text { miles from, on south abutment of Moody Brook Bridge, east of track; } \\
\text { point marked "U.S.184" } \ldots \ldots \ldots \ldots \ldots \ldots \ldots \ldots \ldots \ldots \ldots \ldots \ldots \ldots \ldots \ldots \ldots \ldots \ldots \ldots \ldots \ldots \ldots\end{array}$ \\
\hline 15. 2 & $\begin{array}{l}\text { Lewiston, } 5.3 \text { miles from, on west abutment of Crowley's bridge, south of track; } \\
\text { point marked "S" } \ldots \ldots \ldots \ldots \ldots \ldots \ldots \ldots \ldots \ldots \ldots \ldots \ldots \ldots \ldots \ldots \ldots \ldots \ldots \ldots \ldots \ldots\end{array}$ \\
\hline 20.6 & Lewiston, on west end of dam No. 4 Union Water Power Company; point marked \\
\hline 24.9 & 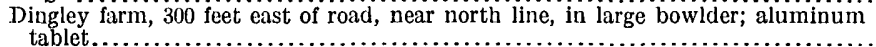 \\
\hline \multirow[t]{2}{*}{26.7} & 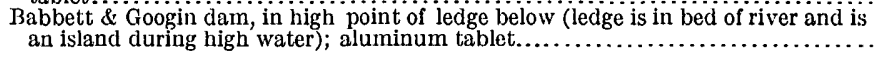 \\
\hline & IIVERMORE QUADRANGLE. \\
\hline 36.2 & 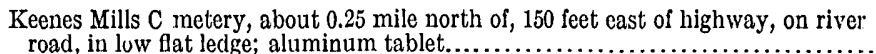 \\
\hline 45.6 & 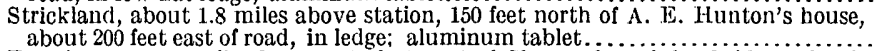 \\
\hline 50.9 & $\begin{array}{l}\text { Farmington, } 17.6 \text { miles from east abutment of Shuey plate-girder bridge; alumi- } \\
\text { num tablet. } \ldots \ldots \ldots \ldots \ldots\end{array}$ \\
\hline 51.9 & Livermore Falls, in southwest corner of post-office building; aluminum tablet...... \\
\hline
\end{tabular}

175.421

111. 231

186. 683

190.098

170. 608

265. 527

225.889

283. 111

296.970

300.038

349. 355

FROM LIVERMORE FALLS, ALONG THE MAINE CENTRAL RAILROAD AND THE GRAND

TRUNK RAILWAY AND HIGHWAYS, UP ANDROSCOGGIN RIVER, TO ERROL, N. H.

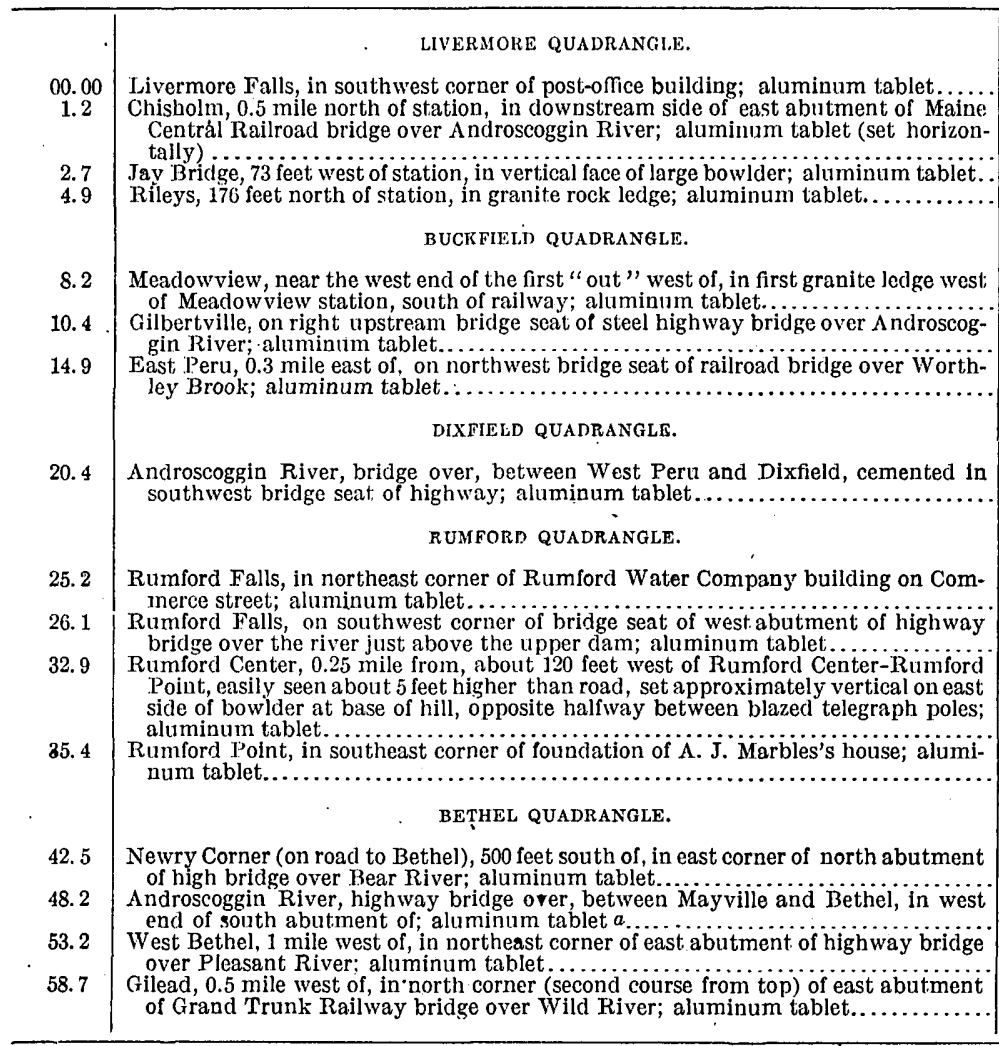


Several unnamed quadrangles.

\section{PEnobscot, Piscataquis, And somerset counties.}

The elevations in the following list of bench marks established by the water-resources branch of the United States Geological Survey, under the general direction of $\mathrm{H}$. K. Barrows, district engineer, were determined from double-rodded primary-level lines run with a 20-inch Gurley wye level and two Philadelphia rods. These elevations result from a preliminary adjustment, under which the elevations at Medway and Moosehead, determined by the primary-level lines of the topographic branch extended from Bangor and Portland were accepted without correction. A new adjustment will not be made unless shown to be advisable when additional primary connections have been made between Penobscot and Kennebec rivers.

In running the base levels of 1905 from Chesuncook to Northeast Carry and from Moosehead west to Jackman, George M. Brett was chief of party. In running the base levels of 1906 on West Branch Penobscot River, from Chesuncook Lake southeast to Norcross, and the base levels of 1907 from Allagash Lake to Grand Lake dam H. S. Boardman was chief of party. In running the base levels of 1908 from Grand Lake dam southeast down East Branch Penobscot River to Medway H. S. Boardman was chief of party and A. L. Grover was instrument man.

Primary leveling by the water-resources branch in several unnamed quadrangles.

FROM CHESUNCOOK TO NOR'THEAST CARRY.

\begin{tabular}{|c|c|c|}
\hline $\begin{array}{l}\text { Distance } \\
\text { in miles. }\end{array}$ & Location and description of bench mark. & $\begin{array}{l}\text { Elevation } \\
\text { in feet. }\end{array}$ \\
\hline & Chesuncook, 18 feet east of post-office, in top of 6 -foot post; iron bol & 934.931 \\
\hline & esuncook, 150 feet south of post-office, in root of stump; nail.. & 931.757 \\
\hline & Chesuncook Hotel, 1,000 feet west of, in telephone pole at top of hill; spike. & $1,009.133$ \\
\hline $\begin{array}{l}1.6 \\
2.5\end{array}$ & Chesuncook, 1.6 miles from, in pine tree on right side of trail; nail.. & 18 \\
\hline 2.94 & $\begin{array}{l}\text { Chesuncook, } 2.94 \text { miles from, } 1,000 \text { feet below mouth of Pinetree Stream, io feet } \\
\text { above water, on right bank of Penobscot River, in ledge; aluminum tablet }\end{array}$ & 49 \\
\hline & 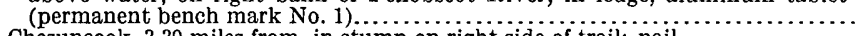 & 936.907 \\
\hline $\begin{array}{l}3.39 \\
3.39\end{array}$ & Chesuncook, 3.39 miles from, in stump on rig & 946.668 \\
\hline 4.17 & 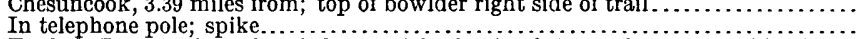 & $\begin{array}{r}949.060 \\
1,005.350\end{array}$ \\
\hline 5.72 & $\begin{array}{l}\text { Foxhole Rips, at foot of, in ledge on right bank of river } \\
\text { manent bench mark No. 2)......................... }\end{array}$ & 945 \\
\hline 6.6 & $\begin{array}{l}\text { Jim Smith's halfway house, } 3.1 \text { miles below, in pine tree at southwest end of field; } \\
\text { nail. }\end{array}$ & \\
\hline 7.3 & In root of $p$ & \\
\hline .95 & In $\mathrm{r}$ & 1.358 \\
\hline $\begin{array}{l}8.14 \\
8.7\end{array}$ & On b & 4.868 \\
\hline & of, in vertical $f$ & \\
\hline & & \\
\hline $\begin{array}{l}10.3 \\
10.5\end{array}$ & at right of trail, $3 \mathrm{fe}$ & $\begin{array}{l}985.635 \\
995.457\end{array}$ \\
\hline & 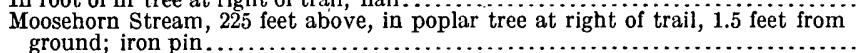 & $990.45 \pi$ \\
\hline 11.9 & In $\mathrm{pc}$ & 97 \\
\hline 13 & & $\begin{array}{l}969.117 \\
969.784\end{array}$ \\
\hline & at left of trail; nail. & 971.249 \\
\hline & In root of spruce tree at left of trail; spike. & 970.814 \\
\hline & $\begin{array}{l}\text { In root of cedar tree at right of trail; spike..... } \\
\text { In root of fir tree at left of trail; spike........ }\end{array}$ & $\begin{array}{l}973.243 \\
973.020\end{array}$ \\
\hline
\end{tabular}


Primary leveling by the water-resources branch in several unnamed quadrangles-Cont'd.

FROM CHESUNCOOK TO NORTHEAST CARRY-continued.

\begin{tabular}{|c|c|c|}
\hline $\begin{array}{l}\text { Distance } \\
\text { in miles. }\end{array}$ & Location and description of bench mark. & $\begin{array}{l}\text { Elevation } \\
\text { in feet. }\end{array}$ \\
\hline 17.59 & In root of fir tree at right of trail; spike. & \multirow{5}{*}{$\begin{array}{l}970.971 \\
979.269 \\
972.198 \\
972.307\end{array}$} \\
\hline 17.9 & $\begin{array}{l}\text { Lobster Stream, east end of bridge over, nearly flush with ground; long iron bolt } \\
\text { driven into top of stump }\end{array}$ & \\
\hline 18.4 & In telephone pole at right of trail; spike & \\
\hline 19.5 & In root of fir tree at left of & \\
\hline 20.5 & $\begin{array}{c}\text { Landing place at river, } 500 \text { feet south from, at left of road to Northeast Carry; top } \\
\text { of bowlder } \ldots \ldots \ldots \ldots \ldots \ldots \ldots \ldots \ldots \ldots\end{array}$ & \\
\hline 21.8 & Northeast Carry, 0.5 mile north of, in root of poplar tree west of road; nail... & \multirow{2}{*}{$\begin{array}{r}980.336 \\
1,077.924\end{array}$} \\
\hline \multirow[t]{3}{*}{22.5} & $\begin{array}{l}\text { Northeast Carry, } 200 \text { feet south west of Winnegarnock House, about } 100 \text { feet from } \\
\text { shore of Moosehead Lake, on top of bowlder; aluminum tablet (permanent }\end{array}$ & \\
\hline & & \multirow{2}{*}{$\begin{array}{l}1,033.429 \\
1,033.594\end{array}$} \\
\hline & 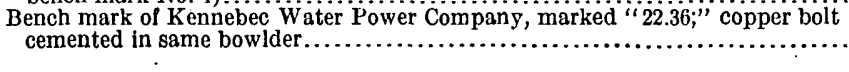 & \\
\hline
\end{tabular}

FROM MOOSEHEAD WEST TO JACKMAN.

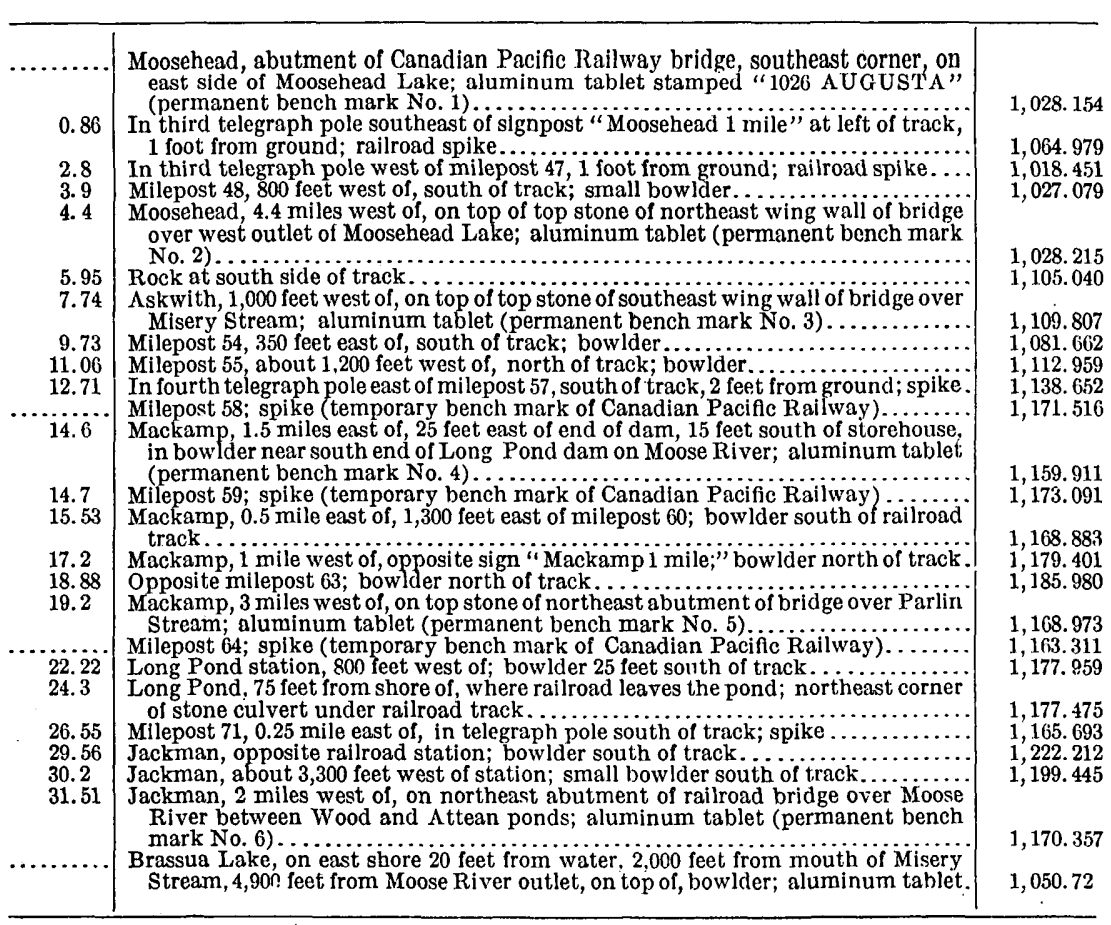

FROM CHESUNCOOK LAKE, SOUTHEAST ON WEST BRANCH PENOBSCOT RIVER, TO NORCROSS.

\begin{tabular}{|c|c|c|}
\hline & Chesuncook Lake, at foot of, 100 feet $s$ & \\
\hline & Northern Paper Company's bench mark No. 15 (elevation given, 945.647). & 943. 019 \\
\hline & Chesuncook dam, near south end of; on large rock marked " $\mathrm{G} S$ " ........ & $\begin{array}{l}936.102 \\
935.440\end{array}$ \\
\hline & $\begin{array}{l}\text { Chesuncook dam, in top of high ledge just south of south wing; aluminum tablet } \\
\text { (permanent bench mark No. 1) } \ldots \ldots \ldots \ldots \ldots \ldots \ldots \ldots \ldots \ldots \ldots \ldots \ldots \ldots \ldots\end{array}$ & 900.710 \\
\hline 0.70 & 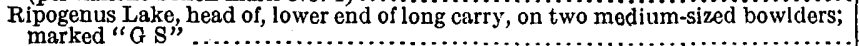 & 752 \\
\hline$\dot{2} .94$ & Ripogenus Lake, foot of, near shore in front of hovel; on rock; marked " $\mathrm{U}$ S & 892. 936 \\
\hline 3.65 & Ripogenus Lake, below, on rock by ledge alon & \\
\hline
\end{tabular}


Primary leveling by the water-resources branch in several unnamed quadrangles-Cont'd.

FROM CHESUNCOOK LAKE, SOUTHEAST ON WEST BRANCH PENOBSCOT RIVER, TO NORCROSS-continued.

\begin{tabular}{|c|c|c|}
\hline $\begin{array}{l}\text { Distance } \\
\text { in miles. }\end{array}$ & Location and description of bench mark. & $\begin{array}{l}\text { Elevation } \\
\text { in feet. }\end{array}$ \\
\hline 4.03 & & \multirow[b]{2}{*}{ 973. 943} \\
\hline 4.40 & $\begin{array}{l}\text { "Elevation } 976.44 \text { " (Great Northern Paper Company's bench mark No. 13) } \\
\text { Carry road, } 2 \text { feet north of, on black rock about } 2 \text { feet wide by } 23 \text { feet long by } 2 \text { feet }\end{array}$ & \\
\hline 7.70 & $\begin{array}{l}\text { high, on top of knoll of putting-in place, small fir } 10 \text { feet west marked "Elevation } \\
799.64 \text { " (Great Northern Paper Company's bench mark No. 12)............... }\end{array}$ & \multirow{2}{*}{ 797. 137} \\
\hline 5.11 & $\begin{array}{l}\text { "The Arches," in ledge, pine tree beside the carry road on which is placed telephone } \\
\text { box bears N. } 80^{\circ} \text { W. } 57 \text { feet, end of wing dam bears about N. } 45^{\circ} \mathrm{E} \text {. } 175 \text { feet; }\end{array}$ & \\
\hline 5.37 & 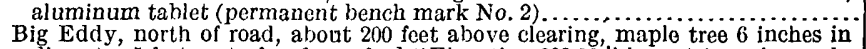 & 724.831 \\
\hline & $\begin{array}{l}\text { diameter } 5 \text { feet east of rock marked "Elevation } 688.96 \text {," large triangular rock; } \\
\text { point of rock (Great Northern Paper Company's bench mark No. 11)............. }\end{array}$ & \multirow[t]{2}{*}{686.487} \\
\hline 5.45 & 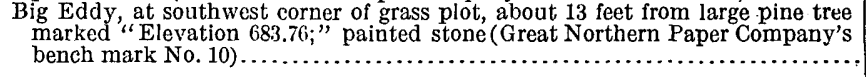 & \\
\hline 5. 49 & Big Eddy, on root of pine tree near camp; turning points marked "U S G S".. & \multirow{4}{*}{$\begin{array}{l}682.640 \\
659.659 \\
659.796 \\
657.867 \\
657.627\end{array}$} \\
\hline 6.48 & 500 feet below foot of falls, on right shore, & \\
\hline 7.28 & Big Ambajemackomus Falls, rock on right shore at head of falls, marked "U $S$ & \\
\hline 8.56 & $\begin{array}{l}\text { Horse race on good-sized white rock near where new telephone line } \\
\text { point of cross marked "B } \mathrm{M} \text { elevation } 623.74 \text {. U S G S" (Gres }\end{array}$ & \\
\hline 8 & $\begin{array}{l}\text { Paper Company's bench mark No. 9) ...... } \\
\text { Horse race, foot of, on right shore, in top of } \mathrm{b}\end{array}$ & \multirow[t]{2}{*}{621.190} \\
\hline 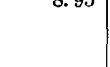 & $\begin{array}{l}\text { Horse race, } 100 t \text { of, on right shore, in top of bowlder on small knoll about } 75 \text { feet } \\
\text { from river, about } 220 \text { feet from dead water, birch tree } 12 \text { inches in diameter bears } \\
\text { west } 12 \text { feet, marked "U S G S B M No. 3;" aluminum tablet (permanent }\end{array}$ & \\
\hline 11.17 & $\begin{array}{l}\text { bench mark No. 3).................. } \\
\text { Sourdnahunk Dead water, foot of, on leit }\end{array}$ & \\
\hline & marl & \multirow{2}{*}{$\begin{array}{l}605.132 \\
604.867\end{array}$} \\
\hline 11.32 & $\begin{array}{l}\text { Sourdnahunk dam, in ledge } \\
\text { tion "S" on cross-section } \\
\text { with nail in center (Great }\end{array}$ & \\
\hline 14.02 & way at island, 250 feet from and on & \multirow{2}{*}{$\begin{array}{l}614.801 \\
569.160 \\
568.767 \\
567.190 \\
566.876\end{array}$} \\
\hline 14. 84 & 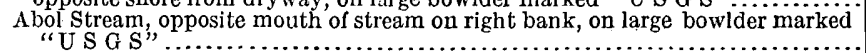 & \\
\hline 15.08 & 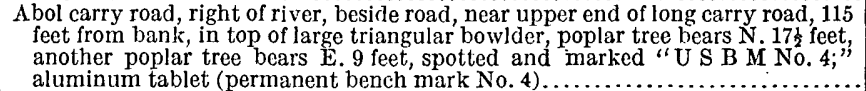 & \multirow{2}{*}{580.275} \\
\hline 15.43 & $\begin{array}{l}\text { A bol Falls, on large round granite rock } 30 \text { feet northeast fro } \\
\text { on carry side of the falls, elevation } 571.945 ; \text { mark (Great } 1 \\
\text { pany's bench mark No. ?) }\end{array}$ & \\
\hline 16.59 & te middie o & \\
\hline 17.64 & bank, about 200 fe & \\
\hline 18.95 & er, foot of, 0.72 mile above head of Debsconeag Falis on & \\
\hline 19.94 & irgest & \multirow{2}{*}{513.910} \\
\hline 19.94 & Debsconeag Falls, on right bank, near lower end of carry road, at foot of falls in & \\
\hline 20.82 & $\begin{array}{l}\text { mark No. 5) } \\
\text { Debsconeag Deadwater, head of, on } \\
75 \text { feet north of landing at Joe Fra }\end{array}$ & 503.705 \\
\hline 22.53 & Pitch, on right & $\begin{array}{l}502.287 \\
502.060\end{array}$ \\
\hline 23.19 & 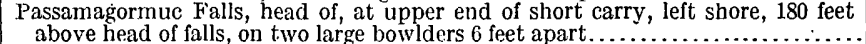 & \multirow{2}{*}{$\begin{array}{l}499.549 \\
499.648\end{array}$} \\
\hline 23.40 & $\begin{array}{l}\text { Passamagormuc Falls, foot of, on rock at puttin } \\
\text { bank in cove; cross on tree marked " } \mathrm{P} \text { e } \\
\text { Great Northern Paper Company's bench ma }\end{array}$ & \\
\hline 24. 36 & alls, on left bank 3 & \\
\hline 25.23 & a (Gre & 514.459 \\
\hline 5.39 & 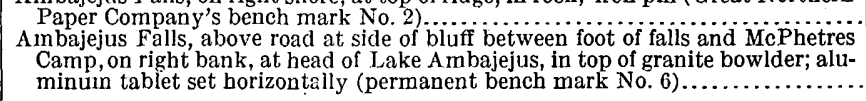 & \multirow{2}{*}{$\begin{array}{l}496.608 \\
483.982 \\
482.622\end{array}$} \\
\hline 25.39 & Ambajejus Falls, near water's edge opposite bench mark No. 6, on large bowlder.. & \\
\hline & $\begin{array}{l}\text { North Twin Lake; Great Northern Paper Company's bench mark, elevation } \\
503.480 \ldots \ldots \ldots\end{array}$ & 503.42 \\
\hline & $\begin{array}{l}\text { Norcross Cove; on bowlder near old boat landing; Great Northern Paper Com- } \\
\text { pany's bench mark, elevation } 488.661 \ldots \ldots \ldots \ldots \ldots \ldots \ldots \ldots \ldots \ldots \ldots \ldots \ldots \ldots \ldots \ldots \ldots \ldots \ldots \ldots \ldots \ldots\end{array}$ & \\
\hline & $\begin{array}{l}\text { North Twin. Lake (4.87 miles south west of Millinocket), top of north pier at } 24 \text { " } \\
\text { foot gate opening; aluminum tablet stamped " } 495 \text { "........................ }\end{array}$ & \\
\hline
\end{tabular}


Primary leveling by the water-resources branch in several unnamed quadrangles-Cont'd.

FROM ALLAGASH LAKE TO GRAND LAKE DAM.

[Distances in miles from Chesuncook.]

5. 00 Umbazooksus Stream, beside carry at head of dead water (elevation 937.04 marked on blazed tree); point on rock (bench mark of Great Northern Paper Company)

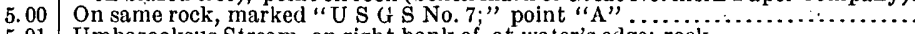

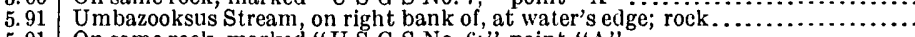

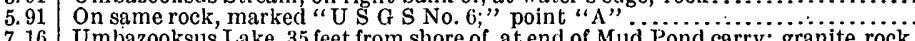

7.16 Umbazooksus Lake, 35 feet from shore of, at end of Mud Pond carry; granite rock.

7.16 On same rock, marked "U S G S No. 5;" point "

8.12 Mud Pond, about 0.8 mile from putting-in place, 5 feet west of Mud Pond carry;

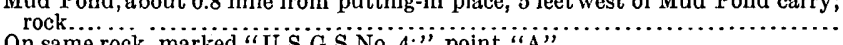

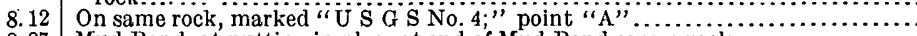

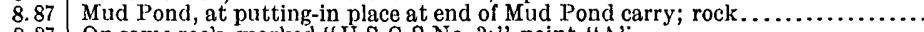

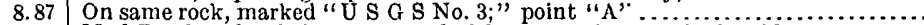

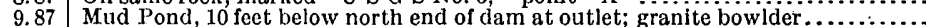

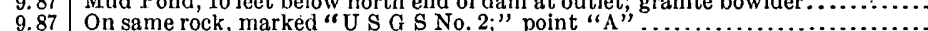

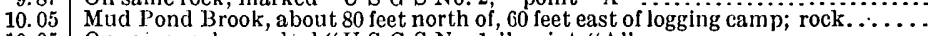

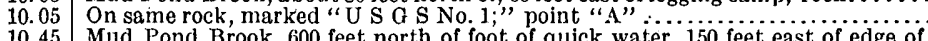

10.45 Mud Pond Brook, 600 feet north of foot of quick water, 150 feet east of edge of woods, on top of outcropping ledge (at high water this ledge is entirely sur-

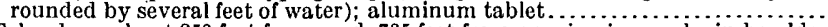

23. 56 Telos dam, about 250 feet from road, 735 feet from opening in woods, in bowider

24.45 Webster Lake, about 75 feet from shore of, in carry between Telo and webster lakes, in turn around; rock.

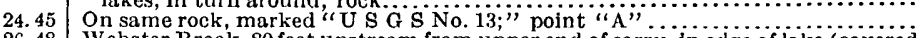
Webster $B$ rook, 80 feet upstream from upper end of carry, in edge of lake (covered in time of high water); rock.

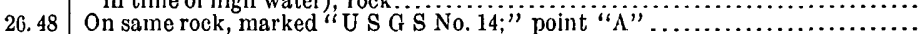

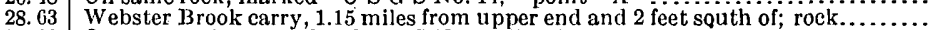

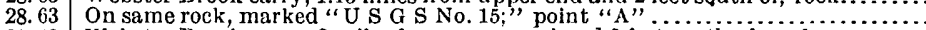

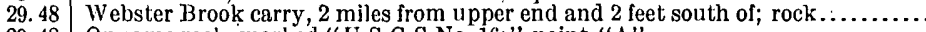

29.48 On same rock, marked "U S G S No. 16;" point " $A$ ".

30.73 Webster Brook carry, 3.25 miles from upper end and south of beside blazed and marked tree; rock.

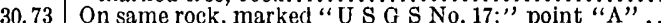

33.36 Indian Pitch, on south bank of Webster Brook, 200 feet upstream from dam, about 10 feet higher than surrounding country and 20 feet from water in brook, in outcropping ledge; aluminum tablet..

34. 73 Webster Brook carry, 10 feet south of, 1.25 miles below dam at Indian Pitch, in root of pine tree; nail.

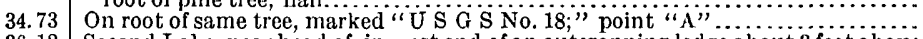

36.12 Second Lake, near head of, in west end of an outcropping ledge about 3 feet above the general surface of ground (ledge gradually rises toward the east, reaching a maximum height of about 35 feet); aluminum tablet...

42.56 Grand Lake, shore of, near Harveys Landing, with chiseled letters and painted white circle around hemispherical head, set flush in ledge; iron bolt marked "U $\odot \mathrm{S}$ "

45.21 Grand Lake dam, 200 feet upstream from west end of, 10 feet from water's edge when gage at dam reads 13.5 leet, in outcropping ledge; aluminum tablet.......

934. 357

934. 332

939. 131

939.558

946.372

947.043

994. 187

994. 142

961.502

961.470

958. 649

958. 379

953. 806

953. 620

946. 234

967. 101

899.463

899.828

895.876

895.717

917. 048

917.069

831.431

830.989

800.849

801.101

790. 385

781.584

781. 251

661.092

656. 111

662.078

CHAMBERLAIN LAKE NORTHWEST TO ALLAGASH LAKE.

9. 60 Allagash Stream, 2 miles below Allagash Falls, in "tote" road near foot of quick water; rock $2 \frac{1}{2}$ feet broad and 1 foot high.

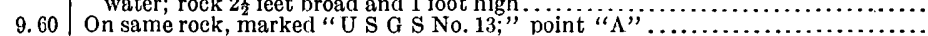

10.60 Allagash Stream, 1 mile below Allagash Falls, 2 feet south of " tote " road; rock....

10. 60 On same rock, marked "U S G S No. 11;" point "A"

11. 60 Allagash Stream, at falls, on left bank of stream, 10 feet below wing dam; rock ledge. . . .

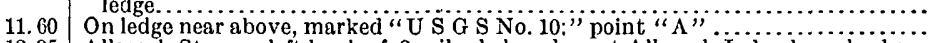

12.95 Allagash Stream, left bank of, 2 miles below dam at $\Lambda$ llagash Lake; large broken

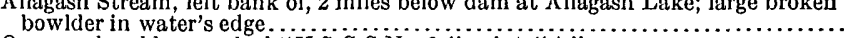

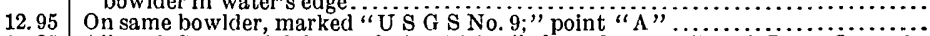

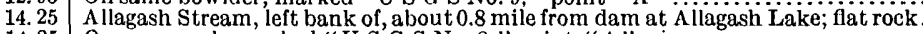

14. 25 On same rock, marked "U S G S No. 8;" point "A"

14. 95 Allagash Lake, 850 feet upstream from dam, about 175 feet from stream in out cropping ledge 15 feet from "tote" road and behind a higher ledge which lies between tablet and stream; aluminum tablet.

945. 763

945. 677

960.033

959.472

987.555

987. 490

992. 347

992.269

$1,015.340$

$1,014.968$

$1,074.037$

53131ำBull. $437-10-2-3$ 
Primary leveling by the water-resources branch in several unnamed quadrangles-Cont'd.

FROM GRAND LAKE DAM, SOUTHEAST DOWN EAST BRANCH PENOBSCOT RIVER, TO MEDWAY.

\begin{tabular}{|c|c|c|}
\hline 5.82 & Stair Falls, at head of lower pitch on right bank, on outcropping ledge 5 to 10 feet & \\
\hline 10.66 & Bowlin Falls, 40 feet from edge of water, on right bank at head of falls, in ledge; & 595.737 \\
\hline 14.05 & 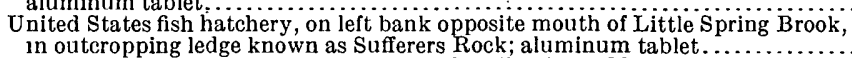 & 401.615 \\
\hline 24. 60 & 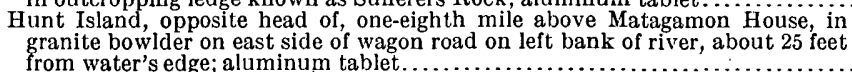 & 52.554 \\
\hline 27.40 & Whetstone Falls, on left bank at foot of falls, about 25 feet from water's edge, about & \\
\hline 33.06 & $\begin{array}{l}150 \text { feet above lower end of carry; rock ledge } \\
\text { Soldiers Brook, } 300 \text { feet above mouth, on right bank, in granite bowlder about } 25 \\
\text { feet from mean low water edge; aluminum tablet. }\end{array}$ & \\
\hline 38.25 & Grindstone, in north end of coping stone on east pier of Bangor and Aroostook & 17.153 \\
\hline 45.59 & 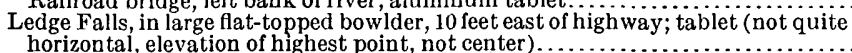 & 285.904 \\
\hline 48. 11 & $\begin{array}{l}\text { Med way, } 0.27 \text { mile west of, } 50 \text { feet east of road, } 120 \text { feet west of house of } \mathrm{A} . \mathrm{T} \text {. Reed, } \\
\text { in ledge; aluminum tablet stamped " } 279 \text {, } \ldots \ldots \ldots \ldots \ldots \ldots \ldots \ldots \ldots \ldots \ldots \ldots \ldots \ldots\end{array}$ & 278.911 \\
\hline
\end{tabular}

\section{NEW HAMPSHIRE.}

\section{PRECISE LEVELING.}

Benton, Campton, Ossipee, Rumney, Silver Lake, Squam Lake, Winnepesaukee, and Woodsville quadrangles.

BELKNAP, CARROLL, AND GRAFTON COUNTIES.

The elevations in the following list are the New Hampshire portion of the results of the line of precise levels run in 1906 by N. A. Campbell from Portland, Me., northwest along the Maine Central Railroad and highways to the Maine-New Hampshire state line; thence across the State of New Hampshire, via Lake Winnepesaukee and South Newbury, Vt., to White River Junction, Vt., where a check was obtained on a bench mark whose elevation was determined by checked primary levels from a tidal bench mark near Portsmouth, N. H. . At White River Junction the elevation of the tablet in the wall of the Catholic Church by precise line from Portland, Me., was 367.777 feet, and by double-primary line from Portsmouth, N. H., 367.022 feet, the weighted mean value adopted being 367.527 feet. The error, 0.250 foot, was distributed over the New Hampshire-Vermont portion.

SILVER LAKE QUADRANGLE.

MAINE-NEW HAMPSHIRE STATE LINE NEAR FREEDOM, NORTHWEST ALONG HIGHWAY TO FREEDOM; THENCE SOUTHWEST TO CENTERVILLE.

East Freedom, in an angle of road forks, in rock; aluminum tablet stamped " $406 "$

Feet.

Freedom, 640 feet from post-office, 50 feet.west of road, in rock; aluminum

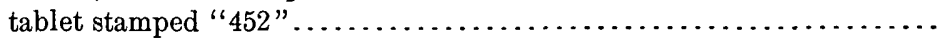

Effingham Falls, 2.2 miles west of, south side of road, in rock; aluminum tablet stamped " 433 "...................................

Centerville, first road northeast of and 300 feet from station; 10 feet from road; aluminum tablet stamped " 529. ". 
OSSIPEE QUADRANGLE.

CENTERVILLE, SOUTH ALONG HIGHWA to OSSIPEe: THENCE SOUTHWEST to WOLFBORO.

Centerville, 3.9 miles southeast of, northeast side of track, 100 feet south of third-class road; aluminum tablet stamped " 598 " ...............

Ossipee, 2.4 miles west of, in southwest corner of field, in rock; aluminum

- tablet stamped " 852 "

Feet.

597.451

Ossipee, 5.4 miles southwest of, about 6 feet northwest of road; aluminum tablet stamped " 660 "

852. 275

Lake Winnepesaukee, August 4,1906 ; surface of water (falling 0.03 foot

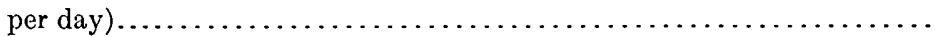

WINNEPESAUKEE QUADRANGLE.

AT MEREDITH.

Meredith; 6-foot mark on gage at wharf

507.031

Meredith, at forks of Wanhaman and Main streets; aluminum tablet stamped " 549 "

\section{SQUAM LAKE QUADRANGLE.}

MEREDITH, NORTHWEST ALONG BOSTON AND MAINE RAILROAD, to PLYMOUTH.

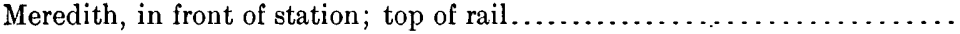

Waukawan Lake; surface of water.

547.9

Meredith, 3 miles northwest of, 25 feet west of track; aluminum tablet stamped " 562 ".

539.0

Ashland, 0.7 mile southeast of, 20 feet northeast of track, in rock; aluminum tablet stamped " 597 "

Ashland, in front of station; top of rail

Bridgewater, in front of station; top of rail.

Bridgewater, 0.4 mile northwest of, west of track, in rock; aluminum tablet stamped " $486 "$

Plymouth, in front of station; top of rail.

561. 710

596. 811

556.6

490. 0

485. 749

483.8

Plymouth, at station, north entrance to baggage room, in stone step; aluminum tablet stamped " 485 ".

\section{CAMPTON QUADRANGLE.}

PLYMOUTH, NORTHWEST 2.6 MILES ALONG BOSTON AND MAINE RAILROAD.

Plymouth, 0.3 mile northwest of, north of track; switch-stand bolt...... 493. 27

RUMNEY QUADRANGLE.

NÉAR PLYMoUth, ALONG Boston AND MAINE RALLOAD, WEST TO WEST RUMNEY AND NORTH TO WARREN SUMMIT.

Plymouth, 3.7 miles northwest of, on northeast side of track, in top of cul-

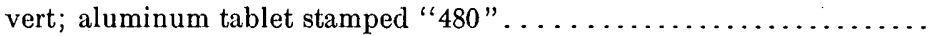

Quincy, in front of station; top of rail. .......................

Quincy, 1.4 miles northwest of, on southwest abutment of overhead highway bridge; aluminum tablet stamped " $511 " . \ldots \ldots \ldots \ldots \ldots \ldots \ldots \ldots$.

Rumney, in front of station; top of rail. ......................

Rumney, 1 mile northwest of, on south abutment of arch railroad culvert; aluminum tablet stamped " 527 ".

510. 430

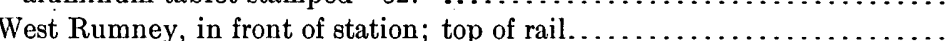

West Rumney, 1.2 miles northwest of, 140 feet east of track, in ledge;

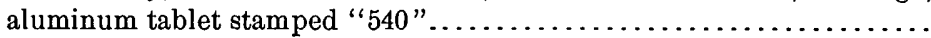


West Rumney, 4.9 miles northwest of, 25 feet east of track, 100 feet northwest of bridge, in field, in ledge; aluminum tablet stamped " 574 ".....

Wentworth, in front of station; top of rail........................

Wentworth, 2.1 miles northwest of, 15 feet east of track, in rock; aluminum tablet stamped " 688 "

Wentworth, 2.9 miles northwest of, road crossing; top of rail . ...........

Warren, 1.5 miles northwest of, in rock, west of track; aluminum tablet stamped " 847 ".

Warren, 4.4 miles northwest of, in rock cut, west of track, in ledge; aluminum tablet stamped "1068".

Glencliff (Warren Summit post-office), in front of station; top. of rail..... 1, 043. 5 .

\section{BENTON QUADRANGLE.}

POINT 3.4 MILES NORTHWEST OF GLENCLIFF, ALONG BOSTON AND MAINE RAILROAD TO POINT 1.4 MILES NORTHWEST OF EAST HAVERHILL.

Glencliff, 3.4 miles northwest of, northeast of track, in bowlder; aluminum

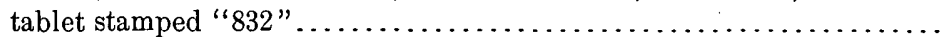

East Haverhill, in front of Boston and Maine Railroad station; top of rail..

East Haverhill, 1.4 miles northwest of, culvert 87; aluminum tablet

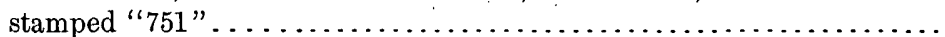

WOODSVILLE QUADRANGLE.

POINT 1.4 MLLES NORTHWEST OF EAST HAVERHILL, ALONG BOSTON AND MAINE RAILROAD, TO HAVERHILL.

Pike, in front of Boston and Maine Railroad station; top of rail...........

Haverhill, at second road crossing west of station, west of track; aluminum

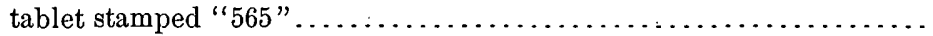

\section{PRIMARY LEVELING.}

\section{Boscawen, Squam Lake, and Winnepesaukee quadrangles.}

BELKNAP, CARROLL, AND GRAFTON COUNTIES.

The elevations in the following list depend on water surface of Lake Winnepesaukee as determined by the precise-level line run with a prism level by N. A. Campbell and party from Portland, Me., in 1906. During August, 1906, gages were established at Wolfboro and Meredith, and observations were taken until September, thereby obtaining a close approximation of the daily water level.

\section{WINNEPESAUKEE QUADRANGLE.}

NEAR LAKE WINNEPESAUKEE.

Melvin, 100 feet north of main road, east of first road to north going west from post-office, in rock; aluminum tablet stamped " 522 " ............

Moultonboro, at road fork northeast of post-office, in rock beside road; aluminum tablet stamped " 597 "............................

Center Harbor, northwest of lake, in lot back of Moulton, 260 feet from

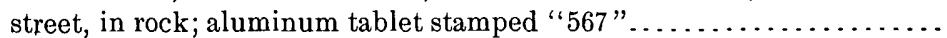

Lakeview, 1.5 miles east of stone entrance to Kona farm, north of road, 15 feet from stone wall, in rock in field; aluminum tablet stamped " 558 " ... Hotel, 100 feet from water's edge and 100 feet north of track, in rock; aluminum tablet stamped " 520 ". 
Lakeport, about 1,200 feet northeast of station, 50 feet west of Lakeshore Railroad, in rock; aluminum tablet stamped " 507 ".

Feet.

Sanders, 0.4 mile west of station, in bowlder north of road; aluminum tablet stamped " 508 ".

West Alton, 300 feet northwest of station, about 50 feet west of track, in rock in apple orchard; aluminum tablet stamped " $570 " . \ldots \ldots \ldots \ldots \ldots . . . . .$.

Mount Major, 240 feet southeast of station, 20 feet west of track, in rock; aluminum tablet stamped " 518 "...........................

Gilford village, 90 feet south of highway to Lakeport, 108 feet west of highway to Laconia, 5 feet from creek, in rock; aluminum tablet stamped "730"

LAKEPORT, ALONG HIGHWAY, TO LACONIA.

Lakeport, in front of station; top of rail.

Laconia, Masonic Temple, on right side of main entrance between pillar and wall of entry; aluminum tablet stamped " 503 "...................

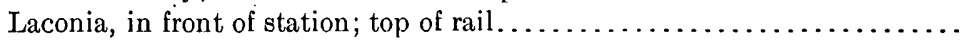

502.768

504.3

\section{BOSCAWEN QUADRANGLE.}

LACONIA TO SANBORNTON.

Laconia, 2.8 miles southwest of, southeast of track, in rock; aluminum tab-

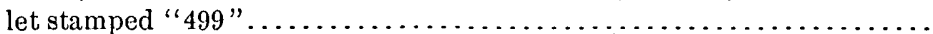

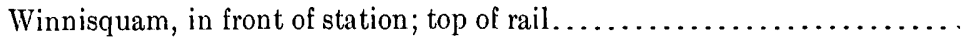

East Tilton village, at road forks, in front yard of school-house, in rock; aluminum tablet stamped " 545 ".

499. 578

490.9

544.444

Sanbornton, 150 feet north of post-office, 8 feet west of road, 10 feet from dwelling house, in rock; aluminum tablet stamped " 824 "...........

SQUAM LAKE QUADRANGLE.

AT MEREDITH CENTER.

Great Bay, September 10, 1906; surface of water.

481. 302

Meredith Center, in front of church, in rock; aluminum tablet stamped " 525 "

AT GAZA.

Gaza, 75 feet southwest of post-office, south of east-west road, in rock; aluminum tablet stamped " 708 "...............................

706. 702

HILL, ALONG BOSTON AND MAINE RAILROAD, TO BRISTOL; THENCE ALONG HIGHWAY, TO BRIDGEWATER STATION.

Hill, in front of station; top of rail.

Hill, at Hill Center-Danbury road forks, west of road to Hill, north of road to Hill Center, in rock; aluminum tablet stamped " 348 "...........

Fill, 2.8 miles northwest of, northeast of track, in bowlder 12 feet above level of track; aluminum tablet stamped " 344 "..................

Bristol, in front of station; top of rail . ............................

Bristol, in public square, soldiers' monument, in pedestal; aluminum tablet stamped " 467 "

New Hampton, in north step of Gordon-Nash Library, in right end of step;

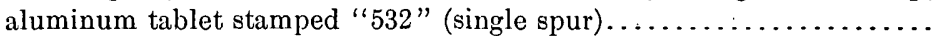

New Hampton, 3.7 miles north of, opposite dwelling house, in.rock, in field;

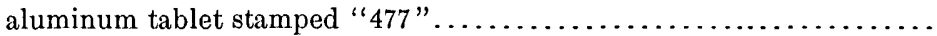

North Sanbornton, in field at northwest corner of road, 80 feet from postoffice, in rock; aluminum tablet stamped " 633 ".

342.708

359.7

465. 498

530.96

476. 778

(i31. 695 
ASHLAND, TO SQUAM LAKE (DOUBLE SPUR LINE).

Holderness, at first road fork east of post-office, in rock; aluminum tablet Feet.

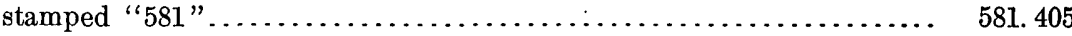

Squam Lake, September 25, 1906; surface of water.................. 559.97

Claremont, Concord, Dover, Hanover, Haverhill, Manchester, Mascony Lake, Milford, Mount Kearsarge, Nottingham, Peterboro, Sunapee, Suncook, and York quadrangles.

CHESHIRE, GRAFTON, HILLSBORO, MERRIMAC, ROCKINGHAM, AND SULliVAN COUNTIES.

The elevations in the following list are based on the gage bench mark at Portsmouth Harbor of the United States Engineer Corps, and of the Coast and Geodetic Survey, consisting of a copper bolt in solid rock 6 feet from wall of old Fort Constitution, opposite cross cut in wall, 3 feet above ground, 127 feet from a wall at right angles to main wall of old fort, 47.9 feet from gate in main wall. The elevation of this bench mark is accepted as 10.17 feet, as determined by the Coast and Geodetic Survey from 143 readings, each of high and low water, taken between September 11 and November 24, 1898. From this point a double-rodded primary-level line was run over the Boston and Maine Railroad, via Manchester, Concord, and Claremont Junction, to White River Junction, Vt., where it connects with the precise-level line from Portland, Me. Of the total closure error of 0.755 foot, 0.5 foot has been corrected by adjustment between Portsmouth and White River Junction. For additional elevations on Hanover and Claremont quadrangles see Vermont list (p. 46).

The leveling was done as follows: In Peterboro quadrangle, by W. R. Harper in 1897; in Dover, Manchester, Nottingham, Suncook, and York quadrangles by F. M. Goodhue in 1903; in Concord, Milford, Mount Kearsarge, Sunapee, and Suncook quadrangles by A. T. Paine in 1904; and in Claremont, Hanover, and Mascony Lake quadrangles by W. A. Anderson in 1905.

\section{YORK QUADRANGLE.}

FORT CONSTITUTION (NEWCASTLE), TO PORTSMOUTH (DOUBLE-RODDED LINE).

Fort Constitution, Newcastle, 6 feet from wall of old fort, opposite cross, 3 feet above ground, cut on wall, 127 feet from a wall at right angles to main wall of old fort, 47.9 feet from gate in main wall, in solid rock; copper bolt 1.75 inches in diameter (Coast and Geodetic Survey and United States Engineer Corps bench mark) ....................

Feet. 10. 170

DOVER QUADRANGLE.

PORTSMOUTH, WEST ALONG BOSTON AND.MAINE RAILROAD, TO HEDDING (DOUBLE-RODDED LINE).

Portsmouth, on street floor of Federal Building, west face of second window from northwest corner, in granite window seat; aluminum tablet stamped "30 CONCORD" 
Rockingham Junction (town of South Newmarket), 0.1 mile east of, 33 feet east of timber pier of overhead highway bridge, 6 feet south of south rail, 5 feet above ground, in shelf of south face of railroad cut through ledge; aluminum tablet stamped " 49 CONCORD"....................

Feet. 49.058

\section{NOTTINGHAM QUADRANGLE.}

BEDDING, WEST ALONG BOSTON AND MAINE RAILROAD TO CANDIA (DOUBLE-RODDED LINE).

Epping, in west face of clock tower, 1 foot from southwest corner of town hall, 18 inches from ground, flush with brickwork; aluminum tablet stamped "129 CONCORD" . . . . . . . . . . . . . . . . . . . . .

Raymond, in foundation of Methodist Church, east face, 1 foot from ground, 2 feet from northeast corner; aluminum tablet stamped " 205 CONCORD"

SUNCOOK QUADRANGLE.

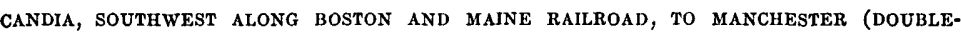
RODDED LINE).

Candia, in south face of granite foundation of town hall, 9 inches from southwest corner, 18 inches above ground; bronze tablet stamped " $498 \mathrm{CON}$ CORD".

Massabesic, 0.2 mile east of station (town of Auburn), on northwest shore of Great Massabesic Lake, in top of large bowlder, 240 feet from track, 5 feet above water; bronze tablet stamped " 255 CONCORD"

MANCHESTER, NORTH TO GARVINS FALLS (DOUBLE-RODDED LINE).

Amoskeag, east side of station, 3.5 feet from ground, in foundation of archway which forms a shed for driveway "for carriages, in large rectangular sandstone; aluminum tablet stamped "200 CONCORD" . . . . . . . . . .

Martins, 0.14 mile due east of station, 200 feet west of four corners east of Martins station, 23 feet west of Mr. Kellogg's farm house, 10 feet south of road, in bowlder; aluminum tablet stamped.

Hooksett, just south of station, in north abutment of red iron railroad bridge over Merrimack River, in northeast corner of north abutment, 5 feet west of bed plate; aluminum tablet stamped "194 CONCORD".

205.048

Robinsons, 0.5 mile north of flag station, in milestone "Concord, 5 miles north; Boston, 69 miles south;" aluminum tablet................

CONCORD QUADRANGLE.

GARVINS FALLS, NORTHWEST ALONG BOSTON AND MAINE RAILROAD, TO CONTOOCOOK (DOUBLE-RODDED LINE).

Bow Junction, 150 feet southeast of station, in large bowlder; aluminum tablet stamped " 236 CONCORD".

236. 354

Concord, at front steps of state capitol, facing east, in large granite stone; aluminum tablet stamped " 288 CONCORD".

287.885

West Concord, 150 feet south of railroad station, at southeast corner of curbing which surrounds the house of $\mathrm{Mr}$. Gray, in large stone; aluminum tablet stamped

Mastyard, 1,000 feet west of flag station, in east abutment of wooden railroad bridge over Contoocook River; aluminum tablet stamped........

Contoocook, opposite post-office, in northwest corner of public fountain; aluminum tablet stamped " 367 CONCORD"
365.736

367.574 
MANCHESTER, WEST ALONG BOSTON AND MAINE RAILROAD, TO PARKER.

Grasmere Junction, 300 feet east of station, 10 feet from track, in ledge; aluminum tablet stamped " 257 CONCORD"

Feet.

256. 906

306.007

318.420
...

CONCORD"

\section{MANCHESTER QUADRANGLE.}

MANCHESTER, SOUTHEAST TO DERRY; THENCE NORTHEAST TO CHESTER; THENCE WEST TO AUBURN.

Manchester, at post-office (federal building), in water table of east buttress of west flight of steps from Hanover street; aluminum tablet stamped " 225 CONCORD".

224.839

Manchester, city hall, in steps of main (Elm street) entrance, in north end of second step from street; brass plug 1.5 inches in diameter.............

Manchester, corner West Auburn street and Depot Square, in top of fire

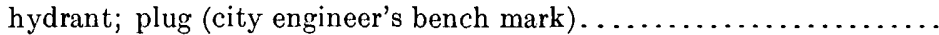

Goffs Falls, bridge over large brook through village, in east end, south abutment, 9 inches outside of rail of bridge, in granite top course; chisel mark.

Derry, in west abutment of steps of Pinkerton Academy; bronze tablet stamped "344 CONCORD" (on short single spur line)..............

Chester, in brick basement of Baptist Church, 15 inches from northeast corner and 18 inches above ground; bronze tablet stamped " $460 \mathrm{CON}$ CORD"

Chester, 2.9 miles northwest of, near Chester-Auburn township line (town of Chester), west of road, 400 feet north of intersection with road to east, in outcrop of ledge; bronze tablet stamped " 361 CONCORD"..........

WEST DERRY, ALONG RAILROAD SOUTHEAST TO WINDHAM DEPOT; THENCE SOUTHWEST TO NASHUA; THENCE NORTH TO GOFFS FALLS.

West Derry, in granite foundation of hook-and-ladder house, north face, 1 foot from northeast corner, 9 inches from ground; aluminum tablet

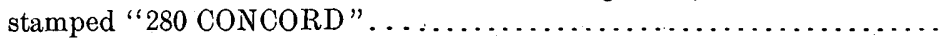

Windham Depot (town of Windham), east side of Worcester, Nashua and Portland track, 400 feet southwest of west crossing of Manchester and Lawrence track (both roads operated by Boston and Maine Railroad), 10 feet from and 4 feet above east rail, in projecting ledge; aluminum tablet stamped " 327 CONCORD" . ..........................

Nashua, in park, corner of Amherst and Concord streets, soldiers' memorial monument, in water table, south face, base (first plinth) of monument; aluminum tablet stamped "168 CONCORD"...................

Merrimack, north of, 0.3 mile north of Reeds Ferry station, east of tracks, at milepost 48 , in top of large bowlder; bronze tablet stamped " $133 \mathrm{CON}$ -

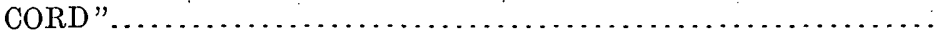

WiNdHam DEPOT, SOUTH TO CANOBIE LAKE (SINGLE SPÚR LINE).

Windham Depot, 4 miles south of (town of Windham), between north ends of Canobie Lake and Cobbett pond, 45 feet from road, in yard at School No. 1, 45 feet from southeast corner of schoolhouse, in ledge; bronze

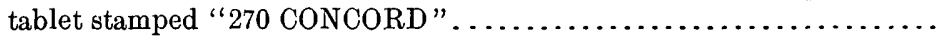


MILFORD QUAADRANGLE.

NASHUA, ALONG BOSTON AND MAINE RAILROAD, to WILTON.

South Merrimack, 250 feet from Milford-Amherst road forks, midway between Dean and Miller cottages, 16 feet north of center of road, in ledge-

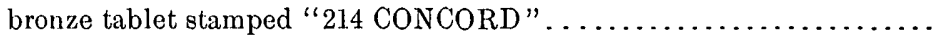

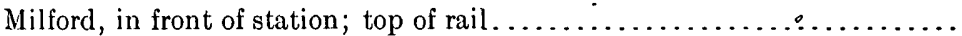

Milford, Unitarian Church, north side, in front base of buttress at portal, 1 foot above ground; bronze tablet stamped " 271 CONCORD"..........

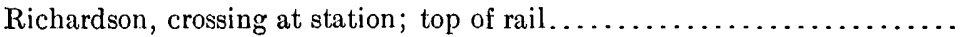

Wilton, 1.5 miles east of, 70 feet north of Jones crossing, on top of south abutment of highway bridge over Souhegan River; aluminum tablet

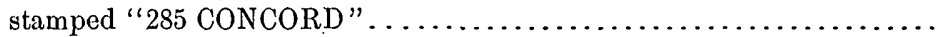

MLLFORD, ALONG AMHERST-NEW BOSTON ROAD, TO PARKER.

Amherst, in foundation of public library, northwest corner, front side of building; aluminum tablet stamped " 269 CONCORD" .............

Amherst, 2.9 miles north of, 0.4 mile south of blind road leading from Amherst-New Boston road to Mount Vernon, in bowlder; aluminum tablet stamped " 489 CONCORD"

Amherst, 6 miles from, on Amherst-New Boston road, 0.2 mile south of four corners, 0.8 mile north of road to Mount Vernon, in bowlder; aluminum tablet stamped " 684 CONCORD".

268.068

489.954

684.216

New Boston, opposite post-office, in northeast corner of front foundation of Presbyterian Church; aluminum tablet stamped "418 CONCORD"....

AMHERST, ALONG BOSTON AND MAINE RALLROAD VIA BEDFORD, TO GRASMERE JUNCTION.

Baboosic, 50 feet northwest of station, in ledge; aluminum tablet stamped " 242 CONCORD".

Bedford, in northeast corner of foundation on front side of Presbyterian Church; aluminum tablet stamped " 325 CONCORD".

MIIFORD, SOUTH ALONG BOSTON AND MAINE RAILROAD TO NORTH BROOKLINE (GPUR LINE).

North Brookline, 289 yards south of road forks, in ledge of rock; aluminum

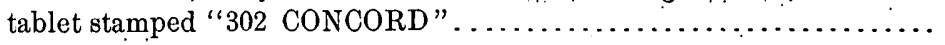

PETERBORO QUADRANGLE.

PETERBoro, ALONG BOSTON AND MAINE RAILROAD, TO ELMWOOD.

Nahors, 243 feet south of crossing, east of railroad and public road, in granite bowlder; copper bolt stamped " 691 ".

689.881

Elmwond, at intersection of the Nashua and Keene and the Peterboro and Hillsboro branches of Boston and Maine Railroad; top of rail..........

Elmwood, 60 feet west of station, in side of triangle formed by tracks, in granite bowlder; copper bolt stamped "692 P"

690.784

ELMWOOD, ALONG BOSTON AND MAINE RAILROAD, TO EAST WILTON.

South Bennington, in front of station; top of rail......................

Greenfield, in front of station; top of rail...........................

Russell, road crossing at station; top of rail.......................

Russell, 1,200 feet south of station, 120 feet north of crossing near schoolhouse, in granite capstone at west side of culvert over brook; copper bolt stamped " $838 \mathrm{P}$ " 
EAST WILTON, VIA WILTON CENTER AND PACK MONADNOCK, TO PETERBORO.

Wilton Center, 0.3 mile south of, near Livermore's sawmill, 60 feet west of road to Wilton Center, 90 feet west of bridge over stream past sawmill, in ledge east of road; copper bolt stamped " $540 \mathrm{P}$ ".................

Feet.

538.088

PETERBoro, ALONG FITCHBURG RAILROAD, TO POINT 1 MILE NORTH OF CHESHIRE MILLS; THENCE TO WILDER.

Peterboro, in front of Fitchburg Railroad station; top of rail.

Peterboro, in north face of square-dressed granite block in foundation supporting porch of entrance to town hall; bronze tablet stamped "744 P"..

Noone, road crossing north of station; top of rail...................

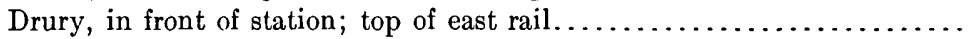

Hadley, at road crossing north of station; top of rail.................

Wilder, 110 feet west of Simon Rolfe's house, 180 feet north of BostonKeene road, at intersection of Sharon and Peterboro roads, in granite bowlder in field; copper bolt stamped "1185 P".

WILDER, VIA HIGH BRIDGE, TO EAST WILTON.

New Ipswich, post-office and store, northeast corner of lower step at east

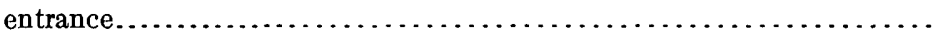

High Bridge, 150 feet south of mill, on Boston-Keene road, stone bridge over Souhegan River; roadway . ............................

Greenville, town hall, in west face of granite foundation stone, 1 foot north of southwest corner of building, 2.5 feet above pavement; bronze tablet stamped "831 P".

810.1

895.0

977. 37

920.5

829. 148

MOUNT KEARSARGE QUADRANGLE.

CONTOOCOOK, WEST ALONG BOSTON AND MAINE RAILROAD, TO BRADFORD (DOUBLERODDED LINE).

Dimond, 600 feet north of flag station, 50 feet west of main road, in large bowlder; aluminum tablet stamped " 421 CONCORD"..............

Warner, road crossing near station; top of rail........................

Warner, on southwest side of Pillsbury Free Library building, at top of stairs, in large rectangular stone; aluminum tablet.................

Roby, 280 feet east of flag station, 50 feet south of track, in large bowlder; aluminum tablet stamped " 518 CONCORD".

Bradford, 400 feet west of station, north of track, in large bowlder; aluminum tablet stamped "684 CONCORD".......................

421.399

411.0

445.437

518. 733

684.268

SUNAPEE QUADRANGLE.

BRADFORD, NORTHWEST ALONG BOSTON AND MAINE RALROAD, TO KELLYVILLE (DOUBLERODDED LINE).

Morse's crossing, 600 feet northwest of, 2 miles southeast of Newbury station, in large bowlder; aluminum tablet stamped................... 952.651

Sunapee Lake, at Newbury, on October 14, 1904; surface of water...... 1, 090.02

Mount Sunapee, 75 feet east of station, in large flat bowlder; aluminum tablet stamped "1125 CONCORD" ........................ 1, 125.374

Spectacle Pond at Mount Sunapee, October 15, 1904; surface of water. . . 1, 113. 74

Sunapee, 800 feet northwest of station, at foundation of stone culvert over brook, in large granite stone; aluminum tablet stamped "927 CONCORD" .........................................

Newport, at south corner of front steps of town hall; aluminum tablet stamped

Kelleyville, 500 feet northeast of flag station, 75 feet north of track, in small bowlder; aluminum tablet stamped " 687 CONCORD"............. 
NEWPORT, SOUTH ALONG HIGHWAYS TO UNITY; THENCE EAST TO GOSHEN; THENCE NORTH TO MOUNT SUNAPEE.

Newport, 5.4 miles south of, 10 feet north of road at East Unity, 50 feet east Feet. of crossroads, in top of ledge; aluminum tablet stamped " $1200 \mathrm{ADJ}$ "... 1, 200.391

East Unity, 3.9 miles southeast of, 100 feet from crossroads, on top of small stone post; point.................................. 020.08

East Unity, 5.1 miles southeast of, 140 feet south of crossroads, 20 feet west of road, in small bowlder; aluminum tablet stamped "1297 ADJ"..... 1, 297.756

Goshen, 5.3 miles north of, near road forks south and east, in southwest corner of red brick house of Joseph Snow; aluminum tablet stamped " 1408

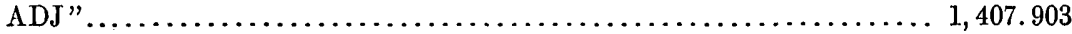

NEWBURY, NORTH ALONG HIGHWAYS TO GEORGES MILLS; THENCE WEST TO CROYDON; THENCE SOUTH TO NORTHVILLE.

Newbury, 3.2 miles north of, at Farmers Corners crossroads, 10 feet north of road, in small bowlder; aluminum tablet stamped " 1293 ADJ"........ 1,292.870

Newbury, 5.9 miles north of, 10 feet from center of crossroads at Goings Corners, in bowlder; aluminum tablet stamped "1193 ADJ"......... 1, 193. 282

Georges Mills, 275 feet east of crossroads, opposite E. Austin's house, 50 feet north of road, in small bowlder; aluminum tablet stamped "1133 ADJ". 1, 133. 546

Georges Mills, 3.7 miles north of, junction of roads west and south called Osborns Corners, 6 feet north of west road, in bowlder; aluminum tablet stamped "1143 ADJ".

Croydon, junction of roads south and east, opposite Gilman's store, 12 feet north of Mr. Sargent's house, in small bowlder; aluminum tablet stamped "912 ADJ"

Croydon Flat, 20 feet north of road, 150 feet west of crossroads, in bowlder; aluminum tablet stamped "806 ADJ" .........................

806. 042

CLAREMONT QUADRANGLE.

KELLEYVILLE, WEST AND NORTH ALONG BOSTON AND MAINE RAILROAD, VIA CLAREMONT JUNCTION, TO WINDSOR, VT. (DOUBLE-RODDED LINE).

Claremont, 2.1 miles west of Chandler flag station, 75 feet north of track, on property of Dennis Cutting, in top of bowlder; aluminum tablet stamped "566 ADJ"

Claremont, in west entrance of town hall, in southeast corner of top step; aluminum tablet stamped " 560 ADJ".

Claremont Junction, 400 feet north of station, 10 feet east of tracks, in top of milepost "W. R. Jc. 22" (one side) and "S 101" (other side); aluminum tablet stamped "478 ADJ"

478. 221

Claremont, 0.25 mile south of town line of Cornish, 0.7 mile south of Balloch station, 30 feet west of track, 35 feet northeast of $A$. W. Lamberton's house, in small flat bowlder; aluminum tablet stamped " 368 ADJ"...........

\section{HANOVER QUADRANGLE.}

HANOVER, EAST ALONG HIGHWAYS to ETNA; THENCE SOUTH TO LEBANON; theNCE WEST ALONG BOSTON AND MAINE RAILROAD TO WHITE RIVER JUNCTION.

Hanover, at corner of College and School streets, in top of sill at northeast corner of front wall of small brick building; aluminum tablet stamped "530 ADJ".

Hanover, 2 miles east of, 170 feet east of M. C. McCabe's house, 12 feet south of road, in top of large flat bowlder; aluminum tablet stamped "594 ADJ" 
Lebanon, at main entrance to town hall, in top of rectangular block of stone; aluminum tablet stamped " $594 \mathrm{ADJ}$ "....................

Feet.

594. 193

NORTH HARTLAND, SOUTHEAST ALONG HIGHWAYS TO MERIDEN; THENCE WEST TO PLANFIELD; THENCE SOUTH TO.WINDSOR.

Meriden, 2.8 miles northwest of, at Pratts Corners, 30 feet northwest of J. L. Pratt's house, in top of small bowlder; aluminum tablet stamped "652 ADJ"

Meriden, 100 feet east of Asa Walker's house, 15 feet north of main road, in top of large ledge; aluminum tablet stamped "925 ADJ".

Meriden, 2.5 miles west of, on Meriden-Plainfield stage road, at junction of road south and west, 340 feet east of D. F. Morgan's house; 50 feet north of road, 10 feet south of large maple, in ledge; aluminum tablet stamped " 800 ADJ".

Plainfield, in front wall of Baptist Church, 1 foot from southeast corner; aluminum tablet stamped " 528 ADJ". . . . . . . . . . . . . . . . . .

\section{MASCONY LAKE QUADRANGLE.}

HANOVER, EAST ALONG HIGHWAY TO ETNA; THENCE SOUTH TO LEBANON; THENCE ALONG BOSTON AND MAINE RAILROAD TO WHITE RIVER JUNCTION.

Etna, 35 feet north of road, 20 feet west of $\mathrm{E}$. C. Wright's house, in top of small bowlder; aluminum tablet stamped " $782 \mathrm{ADJ}$ "...............

Lebanon, 2.5 miles north of, 440 feet south-southeast of log cabin, in top of large bowlder; aluminum tablet stamped " 652 ADJ"

652.470

Whitefield quadrangle.

\section{COOS AND GRAFTON COUNTIES.}

The elevations in the following list, republished from the Nineteenth Annual Report, are based on a bronze tablet set in the west face of stone foundation of McKean Block, Whitefield, facing the public square, marked "W 952", which in turn is based on the top of rail in front of center of Boston and Maine Railroad station, Whitefield, 948 feet. Accordingly the height of the bronze tablet is accepted as 952.419 feet.

The leveling was done in 1897 by Walter R. Harper.

WHITEFIELD, ALONG BOSTON AND MAINE RAILROAD TO HAZEN JUNCTION.

Feet.

Whitefield, opposite Boston and Maine Railroad station; top of rail..... 948. 00

Hazen Junction; top of rail.......................... 1, 036. 69

HAZEN JUNCTION, ALONG MAiNe CENTRAL RAILROAD VIA QUEBEC JUNCTION, TO WAUMBEK JUNCTION.

Hazen Junction; top of rail.............................. 1, 038. 40

Waumbek Junction, at intersection of tracks of the Maine Central and the

Boston and Maine railroads; top of rail........................ 1, 109.61

WAUMBEK JUNCTION, ALONG MAINE CENTRAL RAILROAD VIA RIVERTON, TO LANCASTER.

Waumbek Junction, 200 feet north of intersection of tracks; copper bolt in west side of north abutment of small bridge, stamped "W 1105"..... 1, 105.356

Riverton, opposite station; top of rail of main track............... 1, 045.58

Riverton, 20 feet east of and 4 feet south of station, between station and highway; copper bolt in rock ledge, stamped "W 1044 "........... 1, 044.533 
Lancaster, opposite ticket-office window, Maine Central Railroad station; top of rail, main track.

Feet. 886.81

Lancaster, entrance to Coos County court-house; southeast corner second granite step.

861.49

LANCASTER, WEST ACROSS CONNECTICUT RIVER; THENCE SOUTHWEST ON VERMONT SIDE VIA LUNENBERG BRIDGE, TO WHITEFIELD.

Lancaster, in wall of county court-house, north of entrance; bronze tablet stamped " $864 \mathrm{~W}$ ".

Lancaster, 1 mile west of; floor of highway bridge over Connecticut River. .

Scott, at junction of tracks of the Maine Central and the Boston and Maine

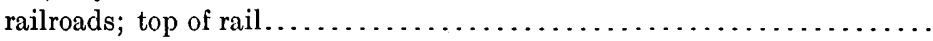

Whitefield, Maine Central Railroad, opposite west line of railroad station;

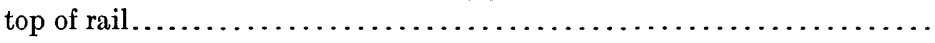

WHITEFIELD, ALONG BOSTON AND MAINE RAILROAD, VIA WING ROAD AND BETHLEHEM JUNCTION, TO TWIN MOUNTAIN.

Whitefield, McKean Block, in west face of stone foundation at northwest corner of building; bronze tablet stamped " $952 \mathrm{~W} " \ldots \ldots \ldots \ldots \ldots \ldots$.

Whitefield Junction, opposite east side of station; top of rail . ............

Wing road, 100 feet east of station, in top of stone or retaining wall at west side of small triangular pond between tracks, back of water tank; copper bolt stamped " $1005 \mathrm{~W}$ "................................ 1, 004. 695

Bethlehem Junction, at north line of station; top of rail ............ 1, 109. 14

Bethlehem Junction, east side of north abutment of covered railroad bridge

(Bethlehem branch) over Ammononoosuc River; copper bolt stamped

"U S G S 1108 Ft. W."..................................., 188. 233

Twin Mountain, opposite west line of Boston and Maine Railroad station; top of rail.

TWIN MOUNTAIN, ALONG MAINE CENTRAL RAILROAD, to QUEBEC JUNCTION.

Twin Mountain, opposite Maine Central station; top of rail............ 1,449. 68

Twin Mountain, 10 feet north of steps leading up to Maine Central Railroad station, 42 feet north by 30 feet west of station, west side of track of Maine Central Railroad; copper bolt in large bowlder, stamped " 1439 W".. 1, 438. 973

\section{Gorham and Milan quadrangles.}

\section{coos counTY.}

The elevations in the following list of bench marks established by the water-resources branch of the United States Geological Survey in 1906 under the general direction of H. K. Barrows, district engineer, were determined by a double-rodded line extended from Augusta, Me., to Brunswick, Me., and thence up the Androscoggin River to Errol, N. H., and are based on mean sea-level determined by a gage bench mark at Portland, Me. For a more detailed description of this line see Maine list (p. 7).

The leveling was done in 1906 by C. Robert Adams and T. W. Norcross. 
Primary leveling by the water-resources branch extended from Augusta, Me.

FROM LIVERMORE FALLS, ALONG THE PORTLAND AND RUMFORD FALLS AND THE GRAND TRUNK RAILWAYS AND HIGHWAYS UP ANDROSCOGGIN RIVER, TO ERROL.

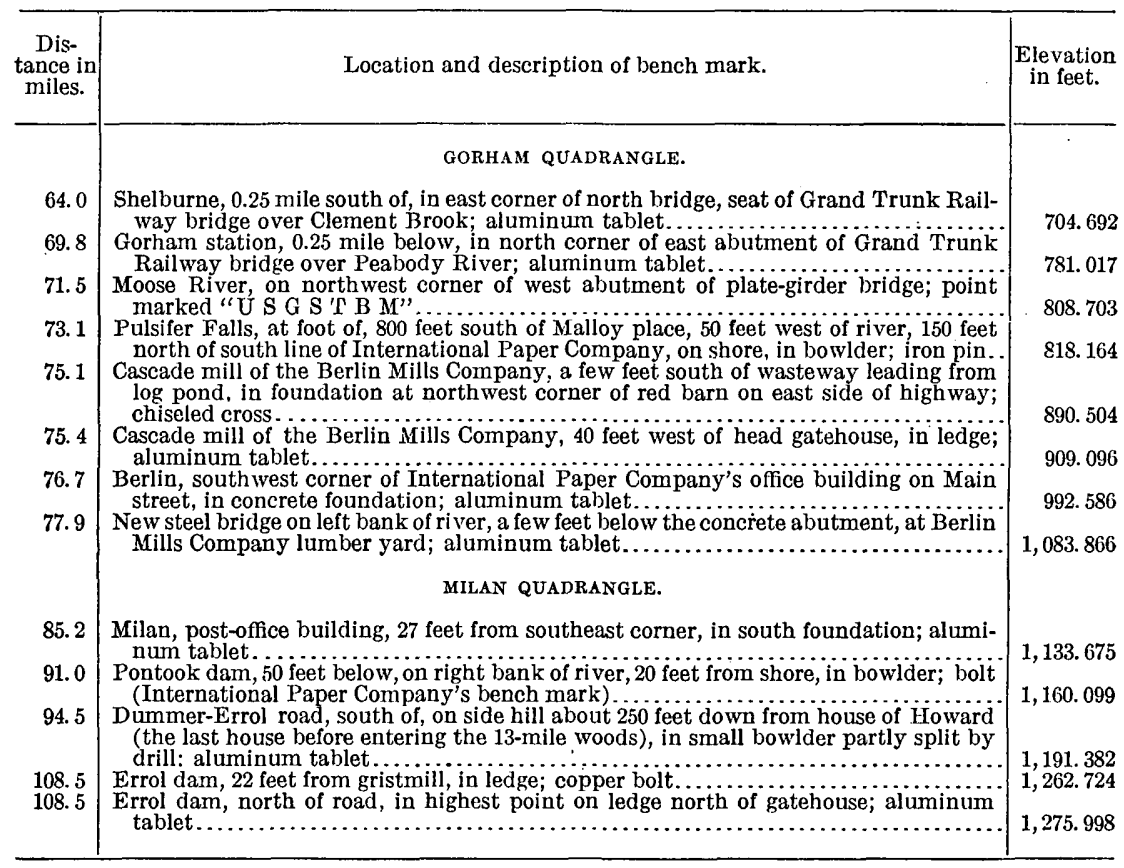

\section{VERMONT.}

\section{PRECISE LEVELING.}

Hanover, Thetford, and Woodsville quadrangles.

ORANGE AND WINDSOR COUNTIES.

The elevations in the following list are the Vermont portion of the results of the line of precise levels run in 1906 .by N. A. Campbell from Portland, Me., northwest along the Maine Central Railroad and highways to the Maine-New Hampshire state line; thence across the State of New Hampshire via Lake Winnepesaukee to South Newbury, Vt.; thence south along the Boston and Maine Railroad to White River Junction. For additional statement, see New Hampshire list (p. 34).

$$
\text { WOODSVILLE QUADRANGLE. }
$$

SOUTH NEWBURY, SOUTH ALONG BOSTON AND MAINE RALROAD, TO BRADFORD.

South Newbury, 0.8 mile southwest of, in bridge abutment; aluminum tablet stamped " $400 "$ ".

South Newbury, in front of station; top of rail.

South Newbury, 2.6 miles southwest of, east of track, in rock; aluminum

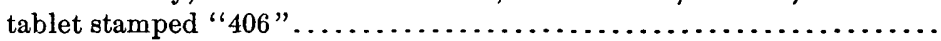

Feet. 400. 152 407.1

405. 716 
THETFORD QUADRANGLE.

BRADFORD, SOUTH ALONG BOSTON AND MAINE RAILROAD, TO POMPANOOSUC.

Bradford, in front of station; top of rail.

Feet.

405. 2

Piermont, in front of station; top of rail . . . . . . . . . . . . . . . . . . .

430.3

Piermont, 1.5 miles southwest of, east of track, at foot of embankment; aluminum tablet stamped " 438 ".

438. 264

Piermont, 3.3 miles southwest of, west of track, in rock ledge; aluminum tablet stamped " 441 "...

440. 500

435. 5

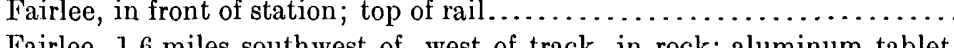
stamped " 414 "

413. 635

Ely, in front of station; top of rail.

396. 2

North Thetford, 0.1 mile southwest of, in abutment of iron bridge over river; aluminum tablet stamped " 399 "

398. 486

Thetford, in front of station; top of rail. . . . . . . . . . . . . . . . . . .

Thetford, 1.6 miles southwest of, east of track, edge of right of way; iron post stamped " 402 ".

408. 3

Pompanoosuc, in front of station; top of rail.

401. 716

392.1

Pompanoosuc, 0.3 mile southwest of, northwest end of railroad bridge; aluminum tablet stamped " 392 "

HANOVER QUADRANGLE.

POMPANOOSUC, SOUTH ALONG BOSTON AND MAINE RAILROAD, TO WHITE RIVER JUNCTION.

Pompanoosuc, 3.25 miles southwest of, 25 feet east of track; iron post stamped " 400 "

Hanover, in front of station; top of rail

399. 952

Hanover, 0.8 mile southwest of, east of track, in rock; aluminum tablet stamped " 412 ".

402.6

Wilder, at side entrance to public library, in top of stone doorsill; aluminum tablet stamped "ADJ 430"

430. 449

408. 7

Wilder, in front of station; top of rail.

365.85

White River Junction, in wall of Catholic Church; aluminum tablet stamped " 367 "

367.527

\section{PRIMARY LEVELING.}

Claremont and Hanover quadrangles.

\section{WINDSOR COUNTY.}

The elevations in the following list were determined by primary leveling extended from and including portions of the double-rodded line of levels begun at Portsmouth, N. H., in 1903 and continued in 1904 and 1905 to West Hartford, Vt. These elevations have been adjusted in conjunction with the precise-level line from Portland, Me., joining this list at. White River Junction.

The leveling in Claremont quadrangle and part of Hanover quadrangle was done by W. A. Anderson in 1905. The remainder of the work in Hanover quadrangle was done by G. M. Dimmick in 1906. 


\section{CLAREMONT QUADRANGLE.}

AT WINDSOR.

Windsor, in west wall of M. E. Church, at corner of South Main and Dursley avenues, 15 feet from corner of building, 2 feet above ground; aluminum tablet stamped " 354 ADJ"..............................

Feet.

354. 011

HANOVER QUADRANGLE.

WINDSOR, ALONG CENTRAL VERMONT RAILWAY TO WEST HARTFORD (DOUBLE-RODDED LINE).

Hartland, 250 feet west of track, in road fork near station, in bowlder 15 feet north of road; aluminum tablet stamped "441 ADJ"..............

North Hartland, 600 feet west of station, 50 feet north of road, 20 feet east of house, on property of William Walker, in top of small bowlder; aluminum tablet stamped "383 ADJ".

441. 825

North Hartland, 1.1 miles north of station, 540 feet north of milepost "Windsor 11 miles," 15 feet east of track, in top of small bowlder; aluminum tablet stamped "349 ADJ".

White River Junction, in Catholic Church, near corner of Gate street, southeast corner of front wall, 8 feet south of doorway; aluminum tablet stamped " 367 ADJ".

Hartford, 2.8 miles west of station, 0.1 mile east of house of Henry Shoch on his property, 120 feet east of road, 410 feet south of track, in top of small bowlder; aluminum tablet stamped " 433 ADJ".

West Hartford, opposite station, 50 feet north of station, 25 feet north of tracks, in projection from ledge, 1 foot above ground; aluminum tablet stamped " 420 ADJ".

WHite RIVER JUNCTION, NORTH ALONG CENTRAL VERMONT RAILWAY, TO NORWICH.

White River Junction, opposite state treasury; top of hydrant............

Wilder, at side entrance of public library, in top of stone doorsill; aluminum tablet stamped "ADJ 430" (recovered by precise levels).

Norwich, near corner of Mechanic and Main streets, in front wall of red brick house owned by Lewin, 10 feet west of doorway; aluminum tablet stamped "536 ADJ".

536. 289

WEST HARTFORD, SOUTH ALONG HIGHWAYS, VIA TAFTSVILLE, TO HARTLAND.

West Hartford, 3.7 miles south of, town of Hartland, in foundation wall of brick schoolhouse, south end of west face; aluminum tablet stamped "941 ADJ".

941. 951

West Hartford, 6.1 miles south of, in foundation of farm house, south end of east face; aluminum tablet stamped " 631 ADJ".

Taftsville, 9.2 miles south of West Hartford, in brickwork of residence of W. H. Taft, west end of south wall, 9 bricks above foundation wall; aluminum tablet stamped " 668 ADJ".

631.339

Taftsville, 2.9 miles south of, 60 feet east of center of highway, 40 feet south of schoolhouse, in rock; aluminum tablet stamped " 954 ADJ"..........

Hartland Four Corners, 7.3 miles south of Taftsville, in brickwork of Universalist Church, east end of north face; aluminum tablet stamped "637 ADJ".

954. 993

Hartland station, 2.6 miles east of Hartland Four Corners, 250 feet west of track, in road fork near station, 15 feet north of road, in bowlder; aluminum tablet stamped "441 ADJ" 
Whitefield quadrangle.

ESSEX COUNTY.

The elevation given below is based on a bronze tablet set in the west face of a stone foundation of McKean Block, Whitefield, facing the public square, and marked "W 952," which in turn is based on the top of rail in front of center of Boston and Maine Railroad station, Whitefield, 948 feet. Accordingly the height of the bronze tablet is accepted as 952.419 feet.

The leveling was done by Walter R. Harper in 1897 .

AT LUNENBERG STATION.

Lunenberg Bridge, Maine Central Railroad covered bridge over Connecticut River; copper bolt in top of west end of south retaining wall at

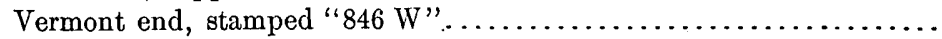

Burlington, Brandon, Camels Hump, Middlebury, Milton, Potato Hill, and Ticonderoga quadrangles.

\section{ADDison, CRITTENDEN, AND RUTLAND COUNTIES.}

The elevations in the following list are based on the 1903 adjusted elevations of bench marks at Ticonderoga and Rouse Point, N. Y., established by the Coast and Geodetic Survey in 1882 and recovered by leveling done under the Deep Waterways Board in 1898 and 1899. The bench mark at Ticonderoga is the bottom of a hole in chiseled circle at southeast corner of north stone abutment of Delaware and Hudson bridge No. 19 over Ticonderoga Creek, and its accepted elevation by the 1903 adjustment is 109.368 feet above mean sea level. The bench mark at Rouse Point is on the water table, north side of Chapman Block, 20.6 feet west of the northeast corner, and consists of a cross and circle, the elevation of which is now accepted as 107.95 feet above mean sea level.

A series of simultaneous gage comparisons was made for seventeen days-June 14-30, 1904-by A. D. Butterfield and H. K. Barrows, of the University of Vermont, between Fort Montgomery, N. Y., and Burlington, Vt., and the elevation thus obtained at Burlington was about 0.3 foot less than that brought from Ticonderoga through primary circuits. The elevations herein given for Burlington quadrangle are based directly on the gage determination, and the error is adjusted in leveling in Ticonderoga and Middlebury quadrangles.

The leveling was done as follows: In Brandon and Ticonderoga quadrangles by George Bailey in 1902; in Middlebury quadrangle by F. M. Goodhue and A. T. Paine in 1903; and in Burlington quadrangle by $\mathrm{A}$. T. Paine in 1904. 


\section{TICONDEROGA QUADRANGLE.}

FORT TICONDEROGA, N. Y., EAST ALONG DELA WARE AND HUDSON RAILROAD, TO WHTING, VT.

Huffs Crossing, 400 feet east of, iron bridge over creek; west end of north

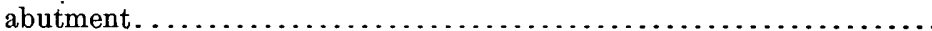

\section{BRANDON QUADRANGLE.}

WHITING, SOUTH ALONG HIGHWAYS, TO SUDBURY (SINGLE SPUR LINE).

Sudbury, northwest corner of church at road corners, on outcrop of rock; bronze tablet stamped "572 ALBANY"....................

WHITING, SOUTHEAST ALONG RAILROAD VIA LEICESTER JUNCTION, TO BRANDON; THENCE NORTHEAST ALONG HIGHWAY, TO FORESTDALE.

Leicester Junction, at road crossing; top of rail.

Brandon, bridge over creek between town hall and First National Bank, in top of west side wall; aluminum tablet stamped "414 ALBANY". .

BRANDON, SOUTHEAST ALONG RAILROAD 3.6 Miles (SINGLE SPUR LINE).

Brandon, 3.36 miles south of, railroad bridge over Otter Creek, north abutment, 4.7 feet east of east rail, 1.3 feet bélow rail; mark . . . . . . . . .

FORESTDALE, NORTH ALONG HIGHWAYS, to EAST MIDDLEBURY; THENCE WEST TO CORNWALL; THENCE SOUTH TO WHITING.

Salisbury, 0.5 mile east of, south side of road corners, 2 feet above ground; bronze tablet stamped " 548 ALBANY" .......................

Cornwall, 3 miles east of, bridge over Otter Creek, on northwest abutment; cut.

Cornwall, in west wall of town hall, just south of door, 1 foot from ground; aluminum tablet stamped " 374 ALBANY".

FORESTDALE, NORTHEAST ALONG HIGHWAYS, TO GOSHEN (SINGLE SPUR LINE).

Goshen, in south end of east wall of meeting house; bronze tablet stamped "1136 ALBANY"

EAST MIDDLEBURY, ALONG HIGHWAYS, TO RIPTON.

East Middlebury, 0.75 mile east of, at road corners. . . . . . . . . . . .

Ripton, north side of highway, bridge over creek, in west abutment; bronze

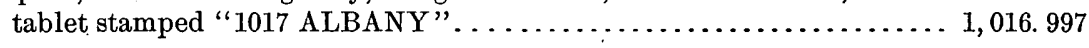

Potato hill quadRaNGLE.

SOUTH LINCOLN TO LINCOLN.

South Lincoln, 0.75 mile, west of, in northwest angle at junction of the South Lincoln and the Lincoln-Ripton roads, in top of granite bowlder, 3.5 feet above ground; bronze tablet stamped "1249 MONTPELIER".. 1, 249. 300

Lincoln, opposite Lincoln Lumber Company's store, in east abutment of iron bridge, south side of roadway, on bridge seat, 15 feet below floor of bridge; aluminum tablet stamped " 971 MONTPELIER"............

\section{MIDDLEBURY QUADRANGLE}

RIPTON, NORTH ALONG HIGHWAYS TO SOUTH LINCOLN.

Ripton, 3.5 miles north of, 75 feet east of bridge over brook, at road fork by Fisher district schoolhouse, in northwest angle at top of retaining wall; on large flat stone; point. 
LINCOLN, WEST ALONG HIGHWAY TO BRISTOL.

West Lincoln, at north end of iron bridge, east side of north abutment; point on bowlder

CORNWALL, NORTH ALONG HIGHWAY AND RUTLAND RAILROAD VIA MIDDLEBURY TO NEW HAVEN; THENCE EAST TO BRISTOL.

Middlebury, in marble underpinning of Battel Block, at middle of bay window at northeast corner of block, 18 inches from sidewalk; aluminum tablet stamped " 366 MONTPELIER"

Belden, in front of station, 6 feet to right of track; point on limestone outcrop.

Brooksville, at south end of iron railway bridge over New Haven River, southeast corner of squared limestone in east side of south abutment; top of second course.

New Haven, in foundation of brick Congregational Church, in north face; 4 feet from northwest corner (corner stone), 15 inches above ground; aluminum tablet stamped " 454 MONTPELIER".................

Bristol, in north face of foundation of town hall (Holley Hall), 18 inches from northeast corner, 1 foot from ground; bronze tablet stamped " 570 MONTPELIER"

NEW HAVEN, NORTH ALONG RUTLAND RAILROAD TO FERRISBURG; THENCE EAST ALONG HIGHWAY TO MONKTON; THENCE SOUTH TO BRISTOL.

Ferrisburg, in foundation of red brick town hall, 10.9 feet from southwest corner of south side, 2.5 feet from ground, in small rectangular limestone; aluminum tablet stamped "217 MONTPELIER"................

Monkton, at four corners, opposite Ladd's Hotel, 500 feet from creamery, on northeast corner of road intersection, in large round rock with flat top; aluminum tablet stamped "533 MONTPELIER"

\section{BURLINGTON QUADRANGLE.}

MONKTON, NORTHWEST ALONG HIGHWAY TO NORTH FERRISBURG; THENCE NORTH ALONG HIGHWAY TO BURLINGTON.

North Ferrisburg, 300 feet from post-office, in northwest corner of foundation of Joseph L. St. Peter's general store, in center of a rectangular sandstone; aluminum tablet stamped " 168 MONTPELIER".

Charlotte, 0.25 mile east of post-office, 25 feet west of three forks forming south point of small triangle of roads, in small flat bowlder with round top; aluminum tablet stamped " 253 MONTPELIER".

252.532

Shelburne, in northwest corner of foundation of Methodist Church, 2 feet from ground, 6 feet from northwest corner; aluminum tablet stamped "174 MONTPELIER".

173.468

Queen City Park, 1.7 miles south of, at northeast angle of three corners, about 100 feet southwest of Spears farmhouse, in small bowlder with flat top; aluminum tablet stamped " 171 MONTPELIER".............

Lake Champlain, at wharf of the Champlain Transportation Company, July 25,1904 ; surface of water.

Burlington, city hall, on south side of front steps facing park, in large rectangular granite capstone, 6 feet above ground; aluminum tablet stamped "208 MONTPELIER" 
MONKTON, NORTHEAST ALONG HIGHWAY TO SOUTH HINESBURG; THENCE NORTH VIA HINESBURG TO WILLISTON; THENCE SOUTHEAST TO RICHMOND.

South Hinesburg, in front foundation of P. McDonough's barn, opposite. cheese factory, 900 feet north of road to Monkton, 25 feet east of main road, 1 foot from ground; aluminum tablet stamped "433 MONTPELIER"

Feet.

433. 248

Hinesburg, north side of town hall, at west edge of marble step, 1 foot above ground; aluminum tablet stamped " 344 MONTPELIER".

Williston, 4 miles southwest of, 4 miles north of Hinesburg, at three corners, 150 feet northwest of red brick schoolhouse, west of road, in large flat slaty bowlder; aluminum tablet stamped "725 MONTPELIER"......

Williston, in southeast corner of front foundation of Methodist Church, 2.5 feet from ground, in small rectangular brownstone; aluminum tablet stamped "501 MONTPELIER"..............................

BURLINGTON, NORTHEAST ALONG CENTRAL VERMONT RAILWAY TO FORT ETHAN ALLEN; THENCE SOUTHEAST TO RICHMOND.

Essex Junction, in foundation of red brick high school, near railroad station, on southeast corner of building, in small rectangular sandstone; aluminum tablet stamped " 358 MONTPELIER".

357.532

North Williston, 150 feet east of station, north of track, opposite red brick gristmill, in middle of bowlder, 1.5 feet above ground; aluminum tablet stamped "305 MONTPELIER"

304.996

CAMELS HUMP QUADRANGLE.

AT RICHMOND.

Richmond, about 600 feet south of station, south of railroad track, in northeast corner of foundation of Universalist Church, in small rectangular red sandstone, 15 feet above ground; aluminum tablet stamped "319 MONTPELIER"

MILTON QUADRANGLE.

AT FORT ETHAN ALLEN.

Fort Ethan Allen, 100 feet east of station, 10 feet from track, in rectangular sandstone, 2 feet above ground; aluminum tablet stamped " 309 MONT. PELIER"

308. 801

\section{Bennington quadrangle.}

BENNINGTON COUNTY.

The elevations in the following list, reprinted from Appendix to Eighteenth Annual Report, are based on a bronze tablet set in the water table at front door of the county court-house in Bennington, marked "U. S. Geological Survey; elevation 682 feet; B. M." The elevation of this bench mark above mean sea level is based on the top of rail of the Rutland Railroad in front of the railroad station at South Shaftsbury, the height of which is accepted as 720 feet, as brought by careful spirit levels from the Delaware and Hudson Railroad at Lake Champlain and adjusted thence through from sea level. In accordance with this height, the elevation of the central datum, the bronze tablet in Bennington, is accepted as 681.611 feet.

The leveling was done by E. L. McNair and A. B. Pomme in 1896. 
AT BENNINGTON.

Bennington, in water table at front door of county court-house; bronze tablet stamped " 682 ".

Feet.

681.611

Main and Bradford streets, corner of south end of stone wall; chiseled circle.

752.40

BENMINGTON, TO BENNINGTON MONUMENT.

Bennington, near convent school, at foot of Monument Hill, on stone south of road, 25 feet east of culvert on west Main street; square chisel mark. .

Bennington monument; on northwest corner of doorsill; chisel mark......

Bennington monument, at left side of entrance doorway; bronze tablet stamped " 873 ".

BENNINGTON, VIA HEARTWELLVILLE, TO STAMFORD.

John Wilson's house, south of road, beside board fence, at east end of bars opening into yard, on small bowlder; chiseled circle .............

John Rooney's house, 50 feet above gate leading to, on top of large bowlder beneath board fence; chiseled circle........................ 1,217.93

Woodford, 2 miles west of, on side of road next to stream; bowlder marked with chiseled circle.

Woodford, 43.5 feet from northwest corner of church, on line with front of church, in large flat bowlder nearly embedded in ground; copper bolt; marked "U S G S 2,215 Ft. B. M."......................... 2, 215. 076

Woodford, 2 miles east of, 160 feet from small wooden bridge, 10 feet south of road, on top of large bowler nearly embedded in ground; chiseled circle............................................. 319.59

Woodford, 5 miles east of, summit of hill surmounted by house, on bowlder near corner of barn; round chisel mark . . . . . . . . . . 267.71

Heartwellville, 2.5 miles north of, about 10 feet east of center of road, 660 feet east of summit of hill, on bowlder; chiseled circle............. 2,446. 01

Heartwellville, east of post-office, 2,100 feet west of Canedy's Hotel, at right of road, in large bowlder; copper bolt stamped "U S G S 1,784 Ft. B. M.". 1, 783. 822

Deerfield River, road fork, 850 feet south of bridge, on large bowlder; chiseled circle...................................... 1,831. 63

Iron bridge, north end of east side, 5 feet from corner, on top of east wall of rock abutment; chiseled circle.

Bennett S. Cole's house, 1,000 feet north of, in meadow at right of road nearly in line with telegraph poles, on top of large bowlder deeply embedded in ground; chiseled circle.

Stamford, Methodist Episcopal parsonage, in doorstep of front porch; copper bolt stamped "U S G S 1,131 Ft. B. M."....................... 1, 130. 762

WOODFORD HOLLOW, TOWARD GLASTENBURY.

Camp Comfort, opposite, 100 feet east of sawmill, 100 feet north of road, on top of large bowlder; chiseled circle.

Electric railway power house, 2.5 miles. from, 10 feet from corner of stable (last building before reaching old town of Glastenbury); copper bolt in bowlder containing about 1 cubic yard, stamped "U S G S 1,672 B. M."... 1, 671.761

BENNINGTON, VIA POWNAL CENTER, TO POWNAL.

Bennington, 0.5 mile south of, east of road at culvert, close to two ash trees, 300 feet north of two dwellings, on large bowlder; square chisel mark...

Bennington, 4.5 miles south of, at Dave Towslee's house, under butternut tree in front of house, on bowlder; square chisel mark............... 
Bennington, 5 miles south of, at Pine Hill, intersection of road to east, just north of Pine Hill, in stone in northeast corner; square chisel mark.....

Pownal Center chureh, 14.75 feet north of northwest corner, in line with front, in rock; copper bolt stamped "U S G S.986 Ft. B. M.".........

Pownal, Main street crossing of Boston and Maine Railroad; top of north rail

Feet.

968.93

985.676

548.55

SOUTH SHAFTSBURY, TO BENNINGTON.

South Shaftsbury, in foundation stone of west abutment, north wing of bridge over small brook; copper bolt stamped "U S G S 711 Ft. B. M."...

South Shaftsbury, I mile south of, on top of corner stone of stone fence in southeast corner of road east, opposite house with 6 black-ash trees in

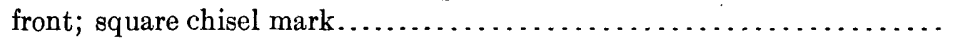

Bennington, 3 miles north of, 300 feet north of brick schoolhouse, at intersection of road east, on lowest stone in southeast fence corner; square chisel mark..........................................

Bennington monument, 1 mile north of, bridge over Furnace Brook, on top of coping of north abutment; square chisel mark.................
710. 83

788. 09

788.87

585.44 


\section{INDEX.}

A.

Page.

Abol Carry

Abol Falls.

Abol Stream.

Adams, C. R., work of

Albany

Albany Corners.

Alexander, C. K., work of............... 16, 20

Allagash Lake......................... 33

Allagash Stream .......................

Ambajejus Falls.......................

Ambajemackomus Falk. ..................

Amherst.

Amoskeag.

Anderson, W. A., work of

Androscoggin River bridge.

Anson.

Anson quadrangle.

Ashland .

Askwith

Auburn.

Augusta.

Augusta quadrangle.

Austin Pond .

B.

Babbett \& Googin dam.

Baboosic.

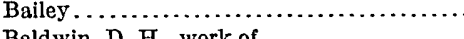

Baldwin, D. H., work of ..................

Bangor.

Bangor quadrangle.

Bath quadrangle.

Bedford.

Belden

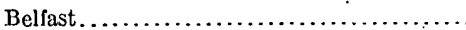

Belfast quadrangle.....................

Bennington

Bennington quadrangle.

Benton quadrangle.

Bethel.

Bethel quadrangle.

Bethlehem Junction.

Big Eddy .

Bingham quadrangle

Bluehill

Bluehill quadrangle .

Boardman, H. S., work of...................

Boscawen quadrangle......................

Bowdoinham.

Bow Junction . ..........................

Bowlin Falls.

Bradford.

Brandon

Brandon quadrangle.
Page. Brassua Lake ........................... 31

Brassua Lake quadrangle................. 13

Brett, G. M., work of.................... 30

Bridgewater.............................

Bridgton Junction....................... 16

Briggs Ferry.......................... 12

Bristol.............................. 37,51

Brooksville........................... 51

Brownfield............................ 10

Brunswick........................... 9,28

Buckfield............................. 15

Buckfield quadrangle.................... 15, 29

Bucksport............................. 20

Bucksport Center......................... 20

Bucksport quadrangle................... 20

Burlington ........................... 51

Burlington quạdrangle................. 51-52

\section{C.}

Camden ............................. 19

Campobell, N. A., work of .................. 8

Camp Comfort.......................... 53

Campton quadrangle.................... 35

Candia................................

Caratunk............................. 12

Cascade mill............................ 46

Castine quadrangle...................... 19

Center Harbor........................... 36

Center Lovell............................ 17

Centerville............................ 34, 35

Charlotte............................... 51

Cherryfield............................ 25,20

Cherryfield quadrangle...................... 25-26

Chester............................... 40

Chesuncook.......................... 30

Chesuncook Lake....................... 31

Chisholm.............................. 29

Claremont............................ 43

Claremont Junction...................... 43

Claremont quadrangle.................. 43,48

Clifton................................ 22

Coe, Robert, work of...................... 19,20

Concord ............................... 39

Concord quadrangle...................... 39-40

Contoocook........................... 39

Cornish............................... 9,16

Cornwall............................... 50

Costigan.............................. 23

Crowleys............................. 14

Crowleys Junction....................... 14

Croydon................................. 43

Croydon Flat.......................... 43

Cumberland Junction..................... 8

Cumberland Mills....................... 8

Cutter................................ $\quad 27$

Cutter quadrangle........................ 27 
D.

Deadwater

Debsconeag Deadwater.

Debsconeag Falls.

Dedham.

Deering Junction

Deering River

Dennysville.

Derry.

Dimmick, G. M., work of..................

Dimond.

Dingley farm...

Dixfield quadrangle.

Douglas, E. M., work of.

Drury...

Drummer-Errol dam

E.

Eastbrook Corners

East Brownfield........................

East Bucksport.

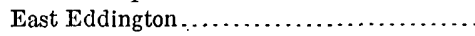

East Freedom.

East Fryeburg. $\ldots \ldots \ldots \ldots \ldots \ldots \ldots \ldots \ldots \ldots \ldots$

East Haverhill .........................

East Hebron.

East Northport........................

East Middlebury.

East Orland.

East Peru.

Eastport.

Eastport quadrangle.

East Stoneham.

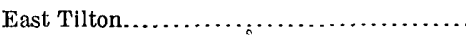

East Unity............................

Edgerly, J. W., work of ............... 19, 20

Effingham Falls....................... 34

Ellingwoods Corner..................... 20

Ellsworth............................. 21

Ellsworth Falls......................... 21,22

Ellsworth quadrangle .................. 21-22

Elmwood............................ 41

Elmwood Farm...................... 14

Ely $\ldots \ldots \ldots \ldots \ldots \ldots \ldots \ldots \ldots \ldots \ldots \ldots \ldots, 47$,

Embden Center....................... 12

Enfield................................. 24

Epping............................... 26, 39

Errol dam............................. 46

Essex Junction................., $\ldots \ldots \ldots, \quad 52$

Etna............................... 44

F.

Fairlee.

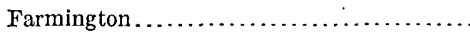

Ferrisburg.

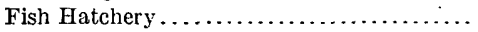

Fort Constitution

Fort Ethan Allen ..........................

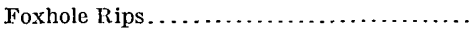

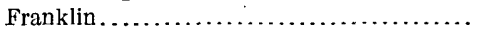

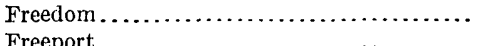

Freeport

Freeport quadrangle.................... 8-9, 29

Fryeburg.............................. 16

Fryeburg Center..................... 17

Fryeburg quadrangle.

$16-17$
G.

Page.

Gannett, S. S., work of .................. 6

Gardiner.............................. $\quad 28$

Gardiner quadrangle.................... 28

Gaza............................. $\quad 37$

Georges Mills.......................... 43

Gilbertville........................ 29

Gilead................................ 29

Gilford.............................. 37

Gilman, H. M., work of ............... 26

Glencliff............................ $\quad 36$

Goffis Falls........................... 40

Goffstown............................. 40

Goodhue, F. M., work of ............... 38, 49

Goodwill............................ 11

Gorham........................... 46

Gorham quadrangle.................... 46

Goshen.............................. 43,50

Grand Lake dam..................... 33

Grasmere Junction...................... 40

Gray quadrangle....................... 8

Great Bay............................ 37

Greenbush............................. 23

Greene............................ 14

Greenfield............................ 41

Greenville............................ 42

Grindstone........................... 34

Grover, A. L., work of ................. $\quad 30$

H.

Hadley $. . \ldots \ldots \ldots \ldots \ldots \ldots \ldots \ldots \ldots \ldots \ldots, 42$

Hallowell................................ 10, 28

Hanover............................ 43,47

Hanover quadrangle............... 43-44,47, 48

Harbor............................. 17

Harper, W. R., work of................ 37,49

Harrington.......................... 26

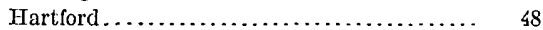

Hartland $. . \ldots \ldots \ldots \ldots \ldots \ldots \ldots \ldots \ldots, 48$

Hartland Four Corners ................... 48

II arts Corners......................... 22

Havens, A. S., work of ................. 20

Haverhill ............................. 36

Hazen Junction....................... 44

Heartwellville......................... 53

Hebron................................ 15

Highbridge........................... 42

Hill.............................. 37

Hillegass, E. B., work of.................... 16

Hinckley............................ 11

Hinesburg............................ 52

Hiram.............................. 16

Holderness............................ 38

Hookset............................. 39

Hudson............................. 21

Huffs Crossing......................... 50

Hunt Island.......................... 34

I.

Indian Pond........................ 12

J.

Jackman............................ 31

Jay Bridge.......................... 29 
K.

Katahdin Stream

Keenes Mills Cemetery.

Kelleyville.

Kenduskeag.

Kezar Falls

Kezar Falls quadrangle.

\section{L.}

Laconia.

Lake Champlain

Lakeport.

Lakeview.

Lakewood.

Lancaster.

Lebanon...

Ledge Falls

Leeds.

Leeds Junction .

Leicester Junction.

Levant....

Lewiston.

Lewiston Junction

Lewiston quadrangle.

I.incoln .

Lincoln Center.

Lincoln quadrangle.

Lincolnville.

Lincolnville Beach.

Lisbon.

Lisbon Falls

Livermore.

Livermore Falls.

Livermore quadrangle.

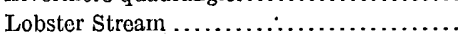

Long Pond.

Lovell.

Lubec.

Lunenberg Bridge.

Lynchville.

\section{M.}

Mackamp.:

McMaugh, F. J., work of.

McNair, E. I., work of..

Madison.

Madison Center.........................

Maine.............................. $7-34$

cooperation of .........................

Manchester.

Manchester quadrangle.

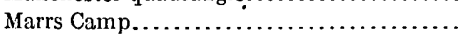

Marshall, R. B., work of..

Martins.

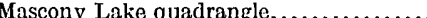

Massabesic.

Mattawamkeag

Mattawamkeag quadrangle

Mattocks.

Meadowview.

Mechanic Falls.

Medway.

Melvin....

Meredith.

Meredith Center.

Meriden.

Merrimack.

Middlebury.
Middlebury quadrangle.

Page. .. 50-51

Milan quadrangle........................ 40

Milford ............................. 22, 41

Milford quadrangle..................... 41

Millbridge............................... 25

Millinocket............................ $\quad 25$

Millinocket Church ...................... 25

Millinocket quadrangle................... $\quad 25$

Monkton.............................. 51

Moosehead:........................... 13, 31

Moosehead Lake....................... 13

Moosehead Lake quadrangle................ 13

Moosehorn Stream..................... $\quad 30$

Moose River........................... 40

Moose's crossing......................... 42

Moultonboro.......................... 36

Mount Desert quadrangle................. $\quad 23$

Mount Kearsarge quadrangle............. 42

Mount Major............................ 37

Moxie Pond........................... 13

Mud Pond.............................. 33

Mud Pond Brook...................... 33

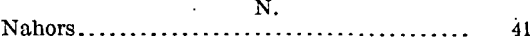

Nashua............................. 40

New Boston......................... 41

Newbury............................ 43

Newhall............................... 8

New Hampshire...................... 34-46

New Hampton........................ 37

New Haven......................... 51

New Ipswich......................... 42

Newport........................... 42,43

Newry.............................. 29

Nicolin................................ 22

Noone.............................. .42

Norcross, T. W., work of................ 28, 45

Norcross Cove.......................... 32

Norridgewock ......................... 11

Norridgewock quadrangle............... 11

North Anson.......................... 12

North Bethel.............................. 18

North Bluehill......................... 23

North Brookline........................ 41

North Bucksport......................... 20

Northeast Carry ......................... 31

North Ferrisburg........................ 51

North Fryeburg........................ 17

North' Hurtland ........................ 48

North Lincoln........................... 24

North Madison......................... 11

North Newburg....................... 20

Northport.............................. 18,19

North Sanbornton...................... 37

North Searsport........................ 20

North Thetford........................ 47

North Twin Lake....................... 32

North Waterford....................... 17

North Williston....................... 52

Norway quadrangle....................... 15

Norwich.............................. 48

Nottingham quadrangle.................. 39

o.

Olamon................................ 23

Old town $. . \ldots \ldots \ldots \ldots \ldots \ldots \ldots \ldots \ldots \ldots \ldots \ldots, 22$

Orland quadrangle...................... 22-23 


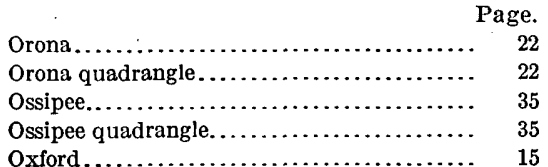

\section{P.}

Packwackamus Deadwater

Packwackamus Falls...................

Paine, A. T., work of................ 38, 49

Parker. ............................ 40

Passadumkeag ......................... 24

Passadumkeag quadrangle................ 23-24

Passamagormuc Falls.................. $\quad 32$

Pejepscot........................... 29

Pembroke.......................... 27

Peterboro............................. 42

Peterboro quadrangle................... 41-42

Piermont............................. 47

Pike............................ $36 . \ldots$

Plainfield............................ 44

Plymouth ......................... 35

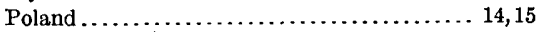

Poland quadrangle. . . . . . . . . . . . . . . . . 14-15

Poland Spring......................... 14

Pomme, A. B., work of............... 52

Pompanoosuc....................... 47

Pontook dam. . . . . . . . . . . . . . . . 46

Porter....................... 9,16

Portland .......................... 8

Portland quadrangle................. 8

Portsmouth.......................... 38

Potato Hill quadrangle................ 50

Pownal............................ 54

Pownal Center ....................... 54

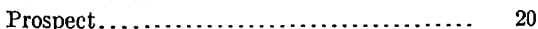

Pulsifer........................ 46

Q.

Queen City Park.

Quincy.

R.

Rands School.

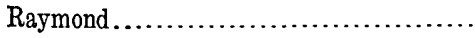

Richardson.

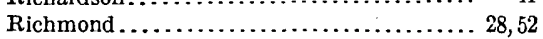

Richville...................... 9

Rileys......................... 29

Ripogenus Lake....................

Ripton.

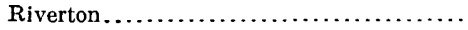

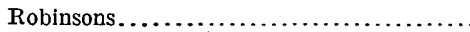

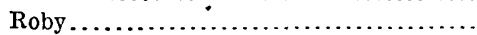

Rockingham Junction.

Rockland

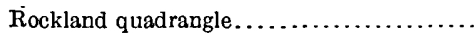

Rumford Center.

Rumford Falls.......................

Rumford Junction.

Rumford Point.

Rumford quadrangle.

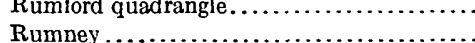

Rumney quadrangle................. $35-36$

Russell.
Sabattus.

S.

Page.

Salisbury.

$\ldots \ldots \ldots \ldots \ldots \ldots \ldots+5, \quad 50$

$\ldots \ldots \ldots \ldots \ldots \ldots \ldots \ldots \ldots \ldots \ldots \ldots \ldots, \quad 37$

Sanders............................. 37

Scott............................. 45

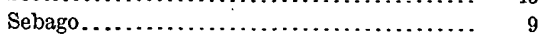

Sebago quadrangle $\ldots \ldots \ldots \ldots \ldots \ldots \ldots \ldots . . . \ldots$

Second Lake. ....................... 33

Shawmut......................... 11

Shelburne...................... 46,51

Silver Lake quadrangle.................. 34

Skowhegan.......................... 11

Skowhegan quadrangle................. 11

Snow Corner........................... 21

Soldiers Brook...................... 34

Solon.............................. 11

Sourdnahunk .................... 32

South Bennington................... 41

South Corinth..................... 21

South Hinesburg. . . . . . . . . . . . . . $\quad 52$

South Lincoln..................... 24,50

South Newbury ...................... 46

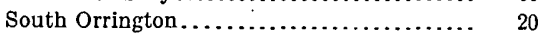

South Paris........................... 15

South Shaftsbury .....................

South Windham .................... 8

Spectacle Pond....................... 42

Squam Lake........................ 38

Squam Lake quadrangle . . . . . . . . . . . 35, 37-38

Stair Falls......................... 34

Stamford .......................... 53

Steep Falls..............................

Steuben.............................. 25

Strickland . . . . . . . . . . . . . . . . . . . . $\quad 29$

Sudbury ............................ 50

Sunapee........................... 42

Sunapee Lake...................... $\quad 42$

Sunapee quadrangle. . . . . . . . . . . . . . . . . . 42-43

Suncook quadrangle.................... $\quad 39$

Surry ......................... 23

Sutton, Frank, work of................ 5

Swanville......................... 18.20

Sweden Corner...................... 17

1 Taftsville....................... 48

The Arches........................

The Forks . . . . . . . . . . . . . . . . . . . . . . 12

The Forks quadrangle................. 12-13

Thetford ........................... 47

Thetford quadrangle $\ldots \ldots \ldots \ldots \ldots \ldots \ldots \ldots \ldots, 47$

The Weirs........................... 36

Thomaston.......................... 19

Thompson Lake....................... 15

Ticonderoga quadrangle.............. 50

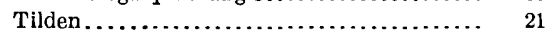

Topsham ........................... 28

Tripp Pond ............................ 15

Turner.............................. 15

Twin Lake dam...................... 25

Twin Mountain..................... 45

U.

Umbazooksus Lake................... 33

Umbazooksus Stream................. 
v.

Page.

Vassalboro.

Vassalboro quadrangle.

Vermont.

W.

Wales.

Waltham

Warner.

Warren...

Washington Junction.

Waterville.

Waterville quadrangle.

Waumbek Junction.

Waukawan Lake.

Webster Brook

Webster Mills.

Wentworth

West Alton...

West Baldwin.

West Bethel.

West Brighton.

West Concord

West Derry.

West Ellsworth.

West Hartford.

West Lincoln.

West Lubec.

West Minot.

West Old town.
Page.

West Pembroke......................... $\quad 27$

West Poland .......................... 15

West Rockport......................... 19

West Rumney ....................... 35, 36

West Winterport....................... 20

Whetstone Falls...................... 34

Whitefield ............................ 44,45

Whitefield quadrangle................ 44-45,49

White River Junction................... 47,48

Whiting.............................. 20

Wilder.............................. 42, 47

Williston........................... 52

Wilson, H. M., work of .................. 5

wilton ............................. 41

Wilton Center........................ 42

Windham Depot. . . ................... 40

windsor............................. 48

Wing road $\ldots \ldots \ldots \ldots \ldots \ldots \ldots \ldots \ldots \ldots, \quad 45$

winn $. . . \ldots \ldots \ldots \ldots \ldots \ldots \ldots \ldots \ldots \ldots \ldots \ldots \ldots, 24$

Winn quadrangle...................... 24

Winnepesaukee, Lake................... 35

Winnepesaukee quadrangle........... $35,36-37$

Winslow ............................ 11

Woodford $\ldots \ldots \ldots \ldots \ldots \ldots \ldots \ldots \ldots \ldots, \quad 53$

Woodsville quadrangle................... 36,46

Yarmouth .......................... 8

Yarmouth Junction...................... $\quad 8,9$

York quadrangle........................ 38 